\title{
Microbial ecology of sea ice at a coastal Antarctic site: community composition, biomass and temporal change
}

\author{
Stephen D. Archer ${ }^{1,2,3}$, Raymond J. G. Leakey ${ }^{1, *}$, Peter H. Burkill ${ }^{2}$, \\ Michael A. Sleigh ${ }^{3}$, Catherine J. Appleby ${ }^{1}$ \\ ${ }^{1}$ British Antarctic Survey, High Cross, Madingley Road, Cambridge CB3 0ET, United Kingdom \\ ${ }^{2}$ Plymouth Marine Laboratory, Prospect Place, The Hoe, Plymouth PL1 3DH, United Kingdom \\ ${ }^{3}$ Department of Biology, University of Southampton, Medical and Biological Sciences Building, Bassett Crescent East, \\ Southampton SO16 7PX, United Kingdom
}

\begin{abstract}
The coastal sea ice in the vicinity of Davis Station, Antarctica ( $\left.68^{\circ} 35^{\prime} \mathrm{S}, 77^{\circ} 58^{\prime} \mathrm{E}\right)$, supported a diverse microbial community which varled in composition and biomass in response to increasing insolation and temperature during the austral summer To understand more fully the fate of photosynthetically fixed carbon in sea ice, we examined the dynamics of community composition, biomass and production in autotrophs, heterotrophic protozoa and bacteria. The microbial community inhabiting the bottom few centimeters of land fast ice differed markedly from the interior communities in taxonomic composition and biomass and in the timing and fate of production. Total microbial biomass integrated throughout the ice depth declined during the season from a mean of $1150 \mathrm{mg} \mathrm{C} \mathrm{m}^{-2}$ on 17 November to $628 \mathrm{mg} \mathrm{C} \mathrm{m}^{-2}$ by 22 December. This largely reflected a decrease in the biomass of the bottom ice community which was dominated by the diatom Entomoneis spp. In contrast, the biomass of the interior ice community increased during summer and was dominated by autotrophic forms $<20 \mu \mathrm{m}$ in length with a small dinoflagellate, Gymnodinium sp., becoming particularly abundant. Heterotrophic protozoa, composed of mainly nanoflagellate, euglenoid and dinoflagellate taxa, contributed between 16 and $19 \%$ of the total integrated microbial biomass in the interior ice and between 1 and $11 \%$ in the bottom sce. The biomass of heterotrophic protozoa increased throughout the ice depth during summer and estimated taxon-specific net growth rates ranged between $0.168 \mathrm{~d}^{-1}$ for a heterotrophic euglenold and $0.05 \mathrm{~d}^{-1}$ for the heterotrophic nanoflagellate population over a $23 \mathrm{~d}$ period. Bacterial biomass varied by several orders of magnitude between ice depths mainly due to the occurrence of an abundant population of large epiphytic bacteria attached to Entomoneis spp. in the bottom ice. However, bacterial biomass contributed a similar proportion of between 4 and $16 \%$ of the total microbial biomass in both interior and bottom ice. The biomass of unattached bacteria increased throughout the ice depth during summer and exhibited an estimated net growth rate of $0.05 \mathrm{~d}^{-1}$ These data are used to quantify autotrophic production in bottom and interior communities, to estimate the flux of carbon to heterotrophs and to illustrate the complexity of the trophic interactions in coastal sea ice.
\end{abstract}

KEY WORDS: Sea ice Antarctica - Micro-organisms - Carbon Blomass

\section{INTRODUCTION}

The magnitude of the oceanic sink for carbon dioxide derived from fossil fuels may be influenced by modulation of the air-sea flux of carbon dioxide by biological activity (Watson et al. 1991). In the Southern ocean, microbial nroduction assoriated with sea ice significantly contributes to overall production and

•E-mail: r.leakey@bas.ac.uk therefore to the biological carbon pump. The most comprehensively studied area is McMurdo Sound, where sea ice autotrophs are estimated to contribute approximately $23 \%$ of the annual net primary production (Knox 1990). Similarly, sea ice autotrophs have been estimated to contribute 22 to $24 \%$ of the total primary production over the vast area of ocean that marks the maximum extent of Antarctic sea ice (Legendre et al. 1992). Therefore, determining the magnitude and fate of the sea ice primary production is a prerequisite 
to understanding the flux of carbon in the surface waters of the Southern Ocean

In marine planktonic and benthic food chains a substantial part of the carbon flow is channeled through heterotrophic micro-organisms. Studies of the bacterial component of sea ice communities suggest they consume a significant proportion of the primary production in Antarctic sea ice (Kottmeier et al. 1987, Grossmann \& Dieckmann 1994, Helmke \& Weyland 1995). In addition, heterotrophic protozoa are now viewed as a dominant biotic control of both phytoplankton (Gifford 1988, Paranjape 1990, Burkill et al. 1993, 1995) and bacterioplankton (McManus \& Fuhrman 1988, Sherr et al. 1989).

A wide variety of heterotrophic protozoa have been found in Antarctic sea ice (Fenchel \& Lee 1972, Lipps \& Krebs 1974, Corliss \& Snyder 1986, Spindler \& Dieckmann 1986, Garrison \& Buck 1989, Stoecker et al. 1993) and the proportion of the protist biomass that they comprise ranges from less than $1 \%$ to greater than 93\% (Garrison \& Buck 1989, 1991, Mathot et al. 1991, Stoecker et al. 1993). There have been no direct measurements of the consumption of primary and bacterial production by heterotrophic protozod in sea ice but several studies suggest that grazing may be a significant factor controlling the development and fate of ice assemblages. For instance, extrapolation of rates reported in the literature for warm water species suggest that in sea ice, consumption by heterotrophic protozoa may exceed the levels of primary production (Garrison \& Buck 1991). An increase in the proportion of heterotrophic to autotrophic protists (Stoecker et al. 1993) and increasing ammonium concentrations (Arrigo et al. 1993a) during spring and early summer in sea ice in McMurdo Sound is further evidence for an active heterotrophic protozoan component.

In the Southern Ocean the extent of sea ice ranges with season from less than $5 \times 10^{\circ} \mathrm{km}^{2}$ to around $20 \times$ $10^{6} \mathrm{~km}^{2}$ (Zwally et al. 1983). The nature of the microbial communities that inhabit sea ice varies in response to the physical processes that form, evolve and deteriorate the ice (reviewed in Palmisano \& Garrison 1993. Ackley \& Sullivan 1994). The major division in sea ice structure and therefore sea ice microbial communities is the distinction between drifting pack ice and the land fast ice. In both pack and fast ice, internal microbial assemblages occur throughout the ice depth but are characterized by relatively low biomass. The bulk of the microbial biomass and production in sea ice is concentrated in characteristic microhabitats. In pack ice, microbial biomass is concentrated in surface and freeboard layers. In contrast, highest biomass and production occurs in fast ice at the base of the ice sheet in bottom and platelet microhabitats. The majority of Antarctic sea ice is pack ice and as a result surface layer and freeboard communities are thought to contribute the majority of the sea ice carbon production in the Southern Ocean (Legendre et al. 1992). However, Ackley \& Sullivan (1994) observed that although fast ice occupies only 1 to $5 \%$ of the total ice cover around Antarctica, standing crops of algae are 3 orders of magnitude greater than those reported for the ice communities of pack ice and therefore the organic carbon. contained in and produced by fast ice communities may be of a similar magnitude to that of the vast expanses of pack ice.

In this paper we describe the seasonal progression in composition, biomass and production of sea ice microbial assemblages including autotrophs, bacteria and heterotrophic protozoa, at a nearshore location in East Antarctica. Land fast ice forms annually in this area and is composed mainly of congelation ice (Scott et al. 1994) consisting of large $(-1 \mathrm{~cm})$ columnar crystals. Previously, several studies based at Australian Antarctic stations have examined the composition and production of the bottom ice algal community in East Antarctica (Bunt 1960, McConville \& Wetherbee 1983, McConville et al. 1985, Perrin et al. 1987). This work has been expanded upon in the present study to include the whole ice depth and to determine the role that the heterotrophic components of the microbial community play in the fate of sea ice primary production.

\section{METHODS}

Sample collection. Sampling was undertaken from mid November 1993 to mid January 1994 at a nearshore location in the vicinity of the Australian Antarctic station of Davis (68 $68^{\circ} \mathrm{S}, 77^{\circ} 58^{\prime} \mathrm{E}$ ) (Fig. 1). Prior to summer breakout of the land fast sea ice on 23 December 1993, sampling was carried out on 3 occasions at a fixed site (O'Gorman Rocks) approximately $1 \mathrm{~km}$ northwest of Davis where the water depth is $22 \mathrm{~m}$. To determine the fate of the microbial community after sea ice breakout, samples were also obtained from pack ice $2 \mathrm{~km}$ northwest of O'Gorman Rocks. A floe was chosen, approximately $400 \mathrm{~m}^{2}$ in area, which had ice depth and snow cover comparable to the O'Gorman Rocks sampling site.

Ice samples were obtained using a SIPRE corer of $76 \mathrm{~mm}$ diameter. Samples were taken from the same $20 \mathrm{~m}^{2}$ area of land fast ice throughout the season before breakout. On each date 3 replicate cores almost $2 \mathrm{~m}$ in length were drilled by hand within a $1 \mathrm{~m}$ radius. Loss of the delicate bottom ice communities may occur when sampling with a SIPRE corer (Welch et al. 1988). However, use of an underwater video camera lowered through an adjacent hole in the ice verified that the 
Fig. 1 Map of study area showing the location of the sampling site (1) on fast ice. at O'Gorman Rocks offshore from the Australian Antarctic station of Davis

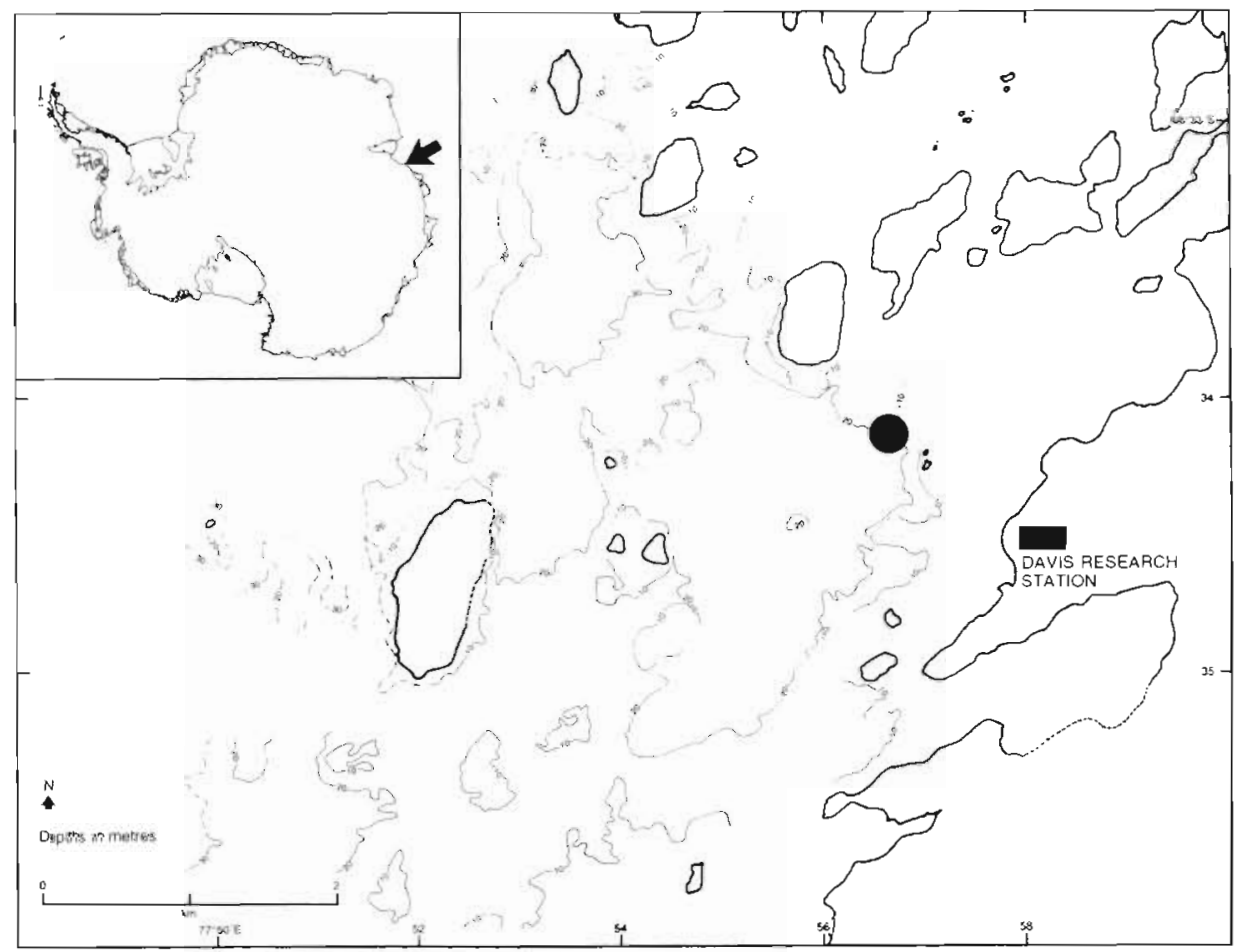

bottom ice community remained intact when coring was carried out with care.

After removal of the snow layer, 5 sections were cut from each core as follows: the top $10 \mathrm{~cm}$ (Horizon A), a middle ice section of $10 \mathrm{~cm}$ (Horizon $\mathrm{B}$ ), two $10 \mathrm{~cm} \mathrm{sec-}$ tions 25 to $5 \mathrm{~cm}$ from the bottom (Horizons $\mathrm{C}$ and $\mathrm{D}$ ), and the bottom $5 \mathrm{~cm}$ of ice (Horizon E). This subsampling regime was chosen to distinguish interior ice communities from a distinctive bottom ice community. Temperature was measured for each horizon using a digital thermometer and each section was then placed in a plastic bag and returned to the laboratory in a cool box for further processing.

Sea ice processing. Core horizons were quartered vertically to provide subsamples for the measurement of chlorophyll a (chl a) and fixation in acid Lugol's iodine, glutaraldehyde and formaldehyde solutions. A dilution technique was employed to reduce osmotic changes and cell loss that occur as sea ice melts (Garrison \& Buck 1986). Subsamples were weighed, prior to melting in a known volume of filtered sea water, to determine an accurate dilution factor of between 1:4 and 1:5 ice to filtered seawater. Fixatives were added to the filtered seawater to produce final concentrations of $1 \%$ Lugol's iodine, $0.3 \%$ glutaraldehyde and $2 \%$ formaldehyde. After melting in the dark at $4^{\circ} \mathrm{C}$ for $12 \mathrm{~h}$, samples were analysed for the quantifiratinn of mirrobial biomass as outlined below.

Microbial biomass. Chl a concentration was determined from 250 to $500 \mathrm{ml}$ samples which were filtered onto GF/F filters under low vacuum and analysed spectrophotometrically following Parsons et al. (1984).

The biomass of the microbial community was estimated from microscopical measurements of taxon specific abundance and cell volume. Bacteria and cells less than $20 \mu \mathrm{m}$ in length were enumerated by epifluorescence microscopy (Hobbie et al. 1977, Porter \& Feig 1980). For bacterial enumeration, 5 to $10 \mathrm{ml}$ of glutaraldehyde fixed sample from each ice horizon was stained with $5 \mu \mathrm{g} \mathrm{ml}^{-1}$ final concentration $4^{1}, 6$ diamidino-2-phenylindole (DAPI), concentrated onto a $0.2 \mu \mathrm{m}$ pore size black polycarbonate filter, and examined at $1250 \times$ magnifjcation under UV illumination. Bacteria were identified by their blue fluorescence and counted from 25 fields of view. For other cells less than $20 \mu \mathrm{m}, 10$ to $30 \mathrm{ml}$ of glutaraldehyde fixed sample from each replicate ice horizon was similarly stained with DAPI, concentrated onto a $2.0 \mu \mathrm{m}$ pore size standard polycarbonate filter, and examined at $1250 \times$ magnifjcation. Cells were identified by their blue fluorescence under UV illumination and grouped into taxonomic categories based on size, shape and morphology. Heterotrophs were distinguished from autotrophs by the absence of chl a autofluorescence observed under blue light illumination. Cells were counted from 28 fields of view. Cells $>20 \mu \mathrm{m}$ were enumerated from settled camples analysed by inverted microscopy (Utermöhl 1958). For each ice horizon, 25 to $50 \mathrm{ml}$ of sample fixed in Lugol's iodine was concentrated by settling for $48 \mathrm{~h}$ and observed at 200 to $400 \times$ magnification. Cells were 
counted from the whole or a representative portion of the settling chamber. Cells were identified to species level where possible from Lugol's samples. To distinguish heterotrophs from autotrophs, cells were concurrently examined by epifluorescence microscopy using samples fixed in formaldehyde and glutaraldehyde.

Cell volumes were determined by image analysis using a Seescan Solitaire Plus system (Seescan plc, Cambridge, UK). Processing of images was restricted to the function 'High Pass' which attempts to reduce gradual shading across an image due to lighting variations or shadows. To aid thresholding of cell borders the function 'Interactive Threshold' allowed the operator to choose the greyshade values of the threshold. In addition, it was possible to include or exclude areas of the image by drawing around them manually. Cell volumes $(V)$ were calculated from measurements of the area $(A)$ and perimeter $(P)$ using the following equations (Fry \& Davies 1985):

$$
v=\left(d^{2} \pi / 4\right)(1-d)+\pi d^{3} / 6
$$

where length (l) and width $(d)$ are:

$$
\begin{gathered}
l=P / 2+(1-\pi / 2) d \\
d=\left[P-\sqrt{\left.\left(P^{2}-4 \pi A\right)\right] / \pi}\right.
\end{gathered}
$$

This calculation assumes that cell shape approximates a cylinder with hemispherical ends and therefore that cell depth is equal to cell width. Taxa with cell shapes that deviated obviously from this assumption required the measurement of a combination of cell profiles to determine cell volume accurately.

For bacteria the volumes of 31 cells from each replicate ice horizon were measured. For all other taxa up to 20 cells were measured for each sampling date Mean cell volumes calculated from $\log _{10}$-transformed data were converted to cell carbon using the following conversion factors: bacteria: $0.40 \mathrm{pg} \mathrm{C} \mu \mathrm{m}^{-3}$ (Bjørnsen \& Kuparinen 1991); heterotrophic nanoflagellates: $0.22 \mathrm{pg} \mathrm{C} \mathrm{mm}^{-3}$ (Børsheim \& Bratbak 1987); ciliates: $0.19 \mathrm{pg} \mathrm{C} \mathrm{m}^{-3}$ (Putt \& Stoecker 1989); and $0.14 \mathrm{pg} \mathrm{C}$ $\mu \mathrm{m}^{-3}$ for heterotrophic dinoflagellates (as quoted in Lessard 1991). All autotrophic and other heterotrophic cell volumes were converted to carbon biomass using the equation:

$$
\text { Cell carbon } \left.(\mathrm{pg})=0.109 \text { [live cell volume }\left(\mu \mathrm{m}^{3}\right)\right]^{0.591}
$$

(Montagnes et al. 1994)

where live volume is $1.33 \times$ preserved volume for cells fixed in Lugol's iodine (Montagnes et al. 1994) and 1.41 $\times$ preserved volume for cells fixed in glutaraldehyde (Verity et al. 1992).

Photosynthetic rate experiments. A modification of the $\mathrm{NaH}^{14} \mathrm{CO}_{3}$ method (Steemann-Nielsen 1952) was used on 2 occasions to estimate the photosynthetic rate of the bottom ice community during the sampling period. Modifications of the method were aimed at preserving the complex sea ice microenvironment and were based upon the method employed by Grossi et al. (1987). On 29 November and 16 December, 3 and 4 cores respectively were collected and the bottom $5 \mathrm{~cm}$ subsampled for each experiment. For each core, a subsample of approximately $50 \mathrm{ml}$ of bottom ice was placed in 1 transparent and 1 darkened $125 \mathrm{ml}$ polycarbonate (Nalgene) bottle. A measured volume of filtered $(0.2 \mu \mathrm{m})$ sea water was then added to fill the bottles and samples were inoculated with $\mathrm{NaH}^{14} \mathrm{CO}_{3}$ (Amersham International plc, Little Chalfont, UK) to a final concentration of $0.08 \mu \mathrm{Ci} \mathrm{ml}^{-1}$. Incubation bottles were secured to a perspex rack and positioned in situ against the bottom ice surface at least $1.5 \mathrm{~m}$ away from the ice hole which was sealed with a polystyrene plug. Sampling was timed to allow dawn-to-dawn $24 \mathrm{~h}$ incubations. Samples were then returned in a cool box and allowed to melt within approximately $1 \mathrm{~h}$ in the dark prior to filtration. From each $125 \mathrm{ml}$ sample two $50 \mathrm{ml}$ aliquots were filtered onto $25 \mathrm{~mm} \mathrm{GF/F}$ filters under low vacuum; one filter was used for analysis of the chl a concentration and the other prepared for liquid scintillation counting These filters were placed in scintillation vials and $2 \mathrm{ml}$ of $5 \%$ glacial acetic acid in methanol added to each. Vials were evaporated to dryness to remove unincorporated ${ }^{14} \mathrm{C}$, and $1 \mathrm{ml}$ of distilled water and $10 \mathrm{ml}$ of scintillation fluid (Optiphase Hi-Safe II, Wallac UK Ltd, Milton Keynes) added prior to scintillation counting. For the determination of photosynthetically fixed dissolved organic carbon a $5 \mathrm{ml}$ subsample of the filtrate was acidified with $0.1 \mathrm{~N} \mathrm{HCl}$ to $\mathrm{pH} 2$ and shaken for $12 \mathrm{~h}$. Three $1 \mathrm{ml}$ subsamples were then radioassayed. The external standards ratio method was used to convert counts per minute (CPM) to disintegrations per minute (DPM). Values for dissolved inorganic carbon from a depth of $5 \mathrm{~m}$ at the time of sampling (Robinson et al. pers. comm.) were used to calculate the amount of ${ }^{14} \mathrm{C}$ fixed. The total amount of carbon fixed was calculated from the sum of the GF/F filter retained and dissolved organic carbon measurements after correction for dark ${ }^{14} \mathrm{C}$ incorporation.

\section{RESULTS}

Sea ice in the vicinity of Davis supported a diverse microbial community which varied in composition and magnitude in response to environmental change.

\section{Environment}

During November 1993 land fast sea ice extended 10 to $15 \mathrm{~km}$ from shore in the vicinity of Davis Station. The 
ice gradually decreased as summer progressed, with a complete breakout occurring on 23 December. After this period the extent of drifting pack ice varied irregularly from 0 to approximately $90 \%$ cover. Increasing insolation, air temperatures and water temperatures were accompanied by a gradual increase in ice temperature and an alteration of ice temperature profile (Table 1). The fast ice consisted of a typically light snow covered area with ice depths that decreased only slightly during the period from a thickness of almost $2 \mathrm{~m}$ (Table 1). Although no systematic ice structural analysis was carried out, ice appeared to be comprised mainly of a columnar structure with regularly spaced vertical brine channels (Weeks \& Ackley 1982). Video examination confirmed the lack of the unconsolidated platelet layer that is often observed under the fast ice of McMurdo Sound. Under-ice video observations also revealed dark green discoloration due to an abundant algal community. In contrast to the fast ice, the pack ice exhibited obvious signs of melting, including a raised freeboard and slush-like layers below the snow cover.

\section{Community composition}

\section{Land fast ice}

In the land fast ice a major distinction in composition and biomass occurred between the bottom (Horizon $E$ ) and interior (Horizons A, B, C and D) ice. An abundant diatom community dominated by Entomoneis spp. inhabited the bottom few centimeters of fast ice. The maximum recorded biomass of Entomoneis spp. was $34 \mathrm{~g} \mathrm{C} \mathrm{m}^{-3}$ on 17 November which contributed $96 \%$ of total microbial biomass in that sample (Table $2 \mathrm{~A}$ ). Although proportionately less significant than Entomoneis spp, other diatoms were abundant. For instance, Pleurosigma sp., Nitzschia stellata and a number of epiphytic species (of the genera Nitzschia and Synedropsis) occurred at a maximum biomass of 309 . 34 and $58 \mathrm{mg} \mathrm{C} \mathrm{m}^{-3}$ respectively (Table $2 \mathrm{~A}$ ). Photosynthetic dinoflagellates including Gymnodinium spp.2, Exuviaella antarctica and Gyrodinium sp. were also common in the bottom ice community (Table 2A) Athecate dinoflagellates are difficult to identify once fixed and the cells grouped under Gymnodinium spp. 2 in Table $2 \mathrm{~A}$ were of a wide size range and may have
Table 1. Depth of ice horizons $(\mathrm{cm})$ and seasonal variation in ice temporature $\left({ }^{\circ} \mathrm{C}\right)$ and hours of sunshine during the sampling perıod 17 November 1993 to 3 January 1994. Ice depth is accurate to within 1-2 cm. Temperatures are centred on that date ND: not determined

\begin{tabular}{|c|c|c|c|c|c|}
\hline & $\begin{array}{l}\text { Date: } \\
\text { Day: }\end{array}$ & $\begin{array}{c}17 \text { Nov } 93 \\
1\end{array}$ & $\begin{array}{c}9 \text { Dec } 93 \\
23\end{array}$ & $\begin{array}{c}22 \text { Dec } 93 \\
36\end{array}$ & $\begin{array}{c}3 \operatorname{Jan} 94 \\
47\end{array}$ \\
\hline \multicolumn{6}{|c|}{ Snow } \\
\hline \multirow{2}{*}{\multicolumn{2}{|c|}{$\begin{array}{l}\text { Depth } \\
\text { Temperature }\end{array}$}} & 10 & $5-10$ & 2.5 & 2.0 \\
\hline & & ND & -0.4 & -0.2 & ND \\
\hline \multicolumn{6}{|c|}{ Ice horizons } \\
\hline \multirow[t]{2}{*}{ A } & Depth & $0-10$ & $0-10$ & $0-10$ & $0-10$ \\
\hline & Temperature & -6.1 & -1.3 & -1.2 & -0.3 \\
\hline \multirow[t]{2}{*}{ B } & Depth & $80-90$ & $80-90$ & $82-92$ & $80-95$ \\
\hline & Temperature & -5.6 & -3.3 & -2.1 & -1.8 \\
\hline \multirow[t]{2}{*}{$\mathrm{C}$} & Depth & $165-175$ & $167-177$ & $160-170$ & $145-155$ \\
\hline & Temperature & -3.0 & -2.3 & -1.9 & -1.2 \\
\hline \multirow[t]{2}{*}{ D } & Depth & $175-185$ & $177-187$ & $170-180$ & $155-165$ \\
\hline & Temperature & -2.5 & -2.0 & ND & -1.2 \\
\hline \multirow[t]{2}{*}{$\mathrm{E}$} & Depth & $185-190$ & $187-192$ & $180-185$ & $165-170$ \\
\hline & Temperature & -2.0 & -1.6 & -1.2 & -1.2 \\
\hline \multicolumn{6}{|c|}{ Ice/water interface } \\
\hline \multicolumn{2}{|c|}{ Temperature } & -1.9 & -1.3 & -0.9 & -1.2 \\
\hline \multicolumn{2}{|c|}{ Sunshine $\left(\mathrm{h} \mathrm{d}^{-1}\right)$} & 6.46 & 21.8 & 21.9 & ND \\
\hline
\end{tabular}

included different species and/or different life history stages. The biomass of Gymnodinium spp.2 reached a maximum of $2.5 \mathrm{~g} \mathrm{C} \mathrm{m}^{-3}$ in the bottom ice, accounting for $36 \%$ of the total microbial biomass in that sample (Table 2A). The motile form of Phaeocystis sp. and the cryptomonad Gemingera cryophila made up the greatest biomass amongst autotrophs of less than $20 \mu \mathrm{m}$ length in Horizon E (Table 2A).

In contrast to the bottom ice, the autotrophic community of the interior ice was dominated by autotrophic forms less than $20 \mu \mathrm{m}$ in length which generally made up greater than $51 \%$ of the biomass in Horizons A, B, C and D (Table 2A, Fig 2). A small dinoflagellate, Gymnodinium sp.1, was particularly abundant. This species closely resembled a small dinoflagellate species described from samples collected in McMurdo Sound by Stoecker et al. (1992). Both vegetative and hypnozygote stages were abundant and occurred throughout the ice. Highest numbers of vegetative cells accurred in Horizon $\mathrm{B}$ with a

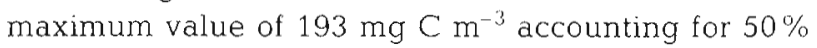
of total biomass (Table 2A). Pennate diatoms, particularly Navicula sp. and a number of species of the genera Nitzschia and Sunedropsis, were abundant in the internal ice (Table 2A). However, diatoms generally accounted for less than $25 \%$ of the total biomass in these horizons (Fig. 2). 

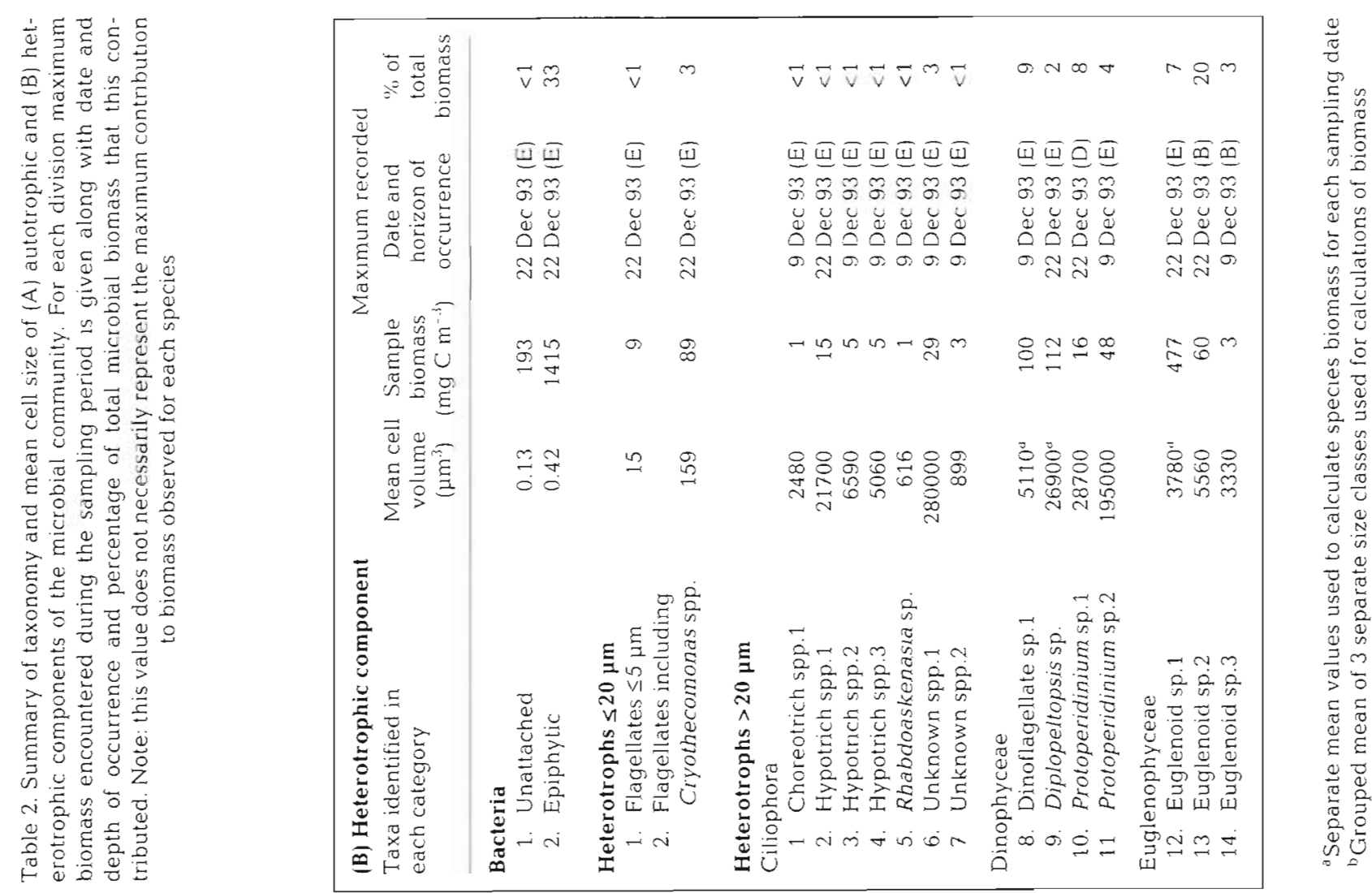

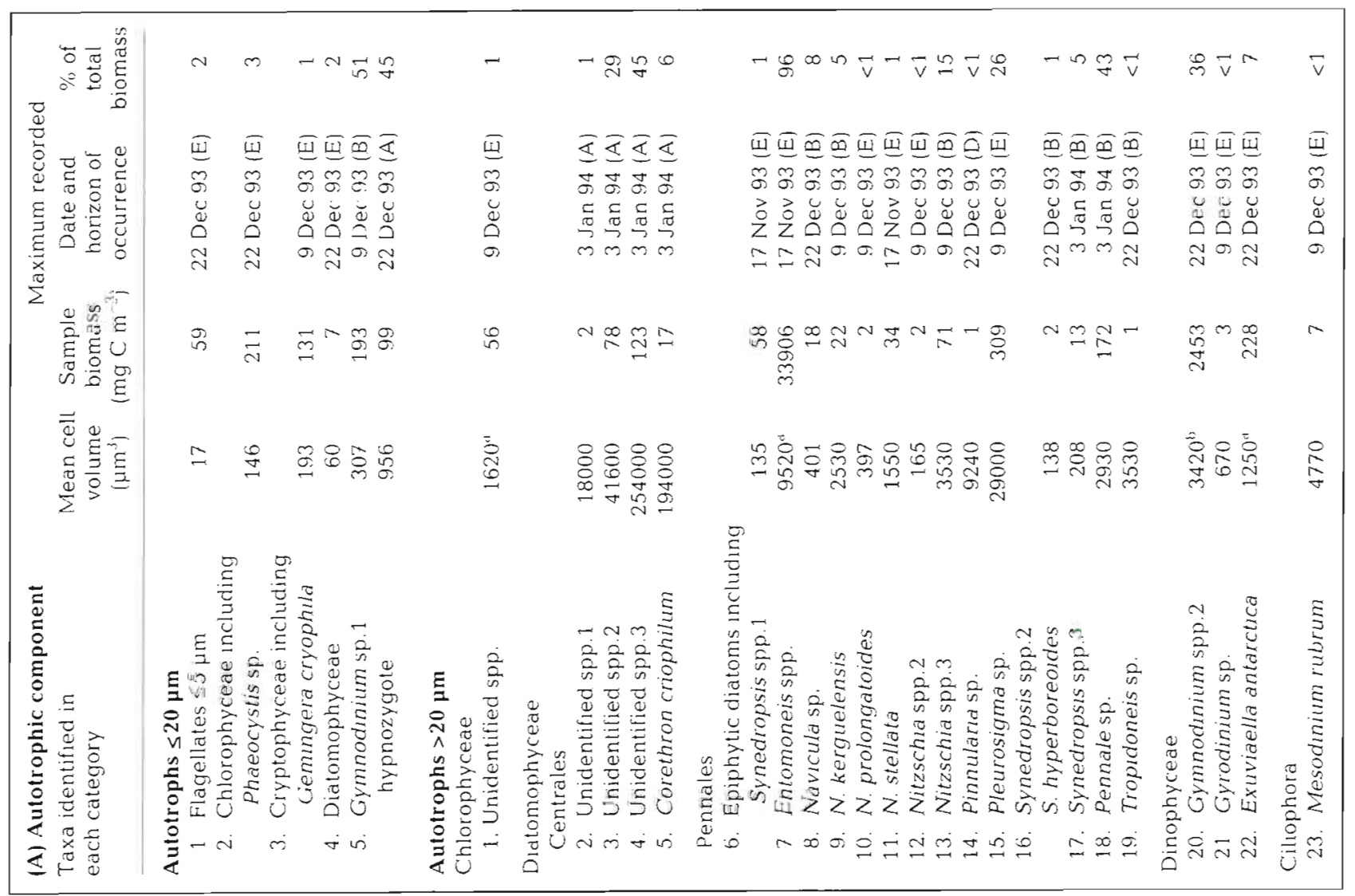


Fig. 2. Mean ( $\mathrm{n}=3$ ) biomass of 6 major categories of autotrophic taxa recorded from 5 ice horizons in cores sampled on 17 November 1993, 9 and 22 December 1993 and 3 January 1994. Details of ice horizon depth are given in Table 1 Note the different scales for Horizon $\mathrm{E}$

Abundant and diverse communities of heterotrophic protozoa inhabited all horizons of the land fast ice (Table 2B, Fig. 3). The dominant heterotrophic taxa occurring in the bottom few centimeters of ice were a species of euglenoid, and 2 dinoflagellates (Fig. 3). Euglenoid sp.1 was characterized by typical squirming movements, a ridged pellicle, 2 emergent flagella of equal length and a possible ingestion organelle (Larsen \& Patterson 1991). The carbon biomass of Euglenoid sp. 1 reached a maximum on 22 December, accounting for $7 \%$ of the total microbial biomass in one sample (Table 2B) and almost $70 \%$ of the mean heterotrophic biomass on that date (Fig. 3). Two dinoflagellates, Diplopeltopsis sp. and Dinoflagellate sp.1, each made up $25 \%$ of the mean heterotrophic protozoan biomass on occa-

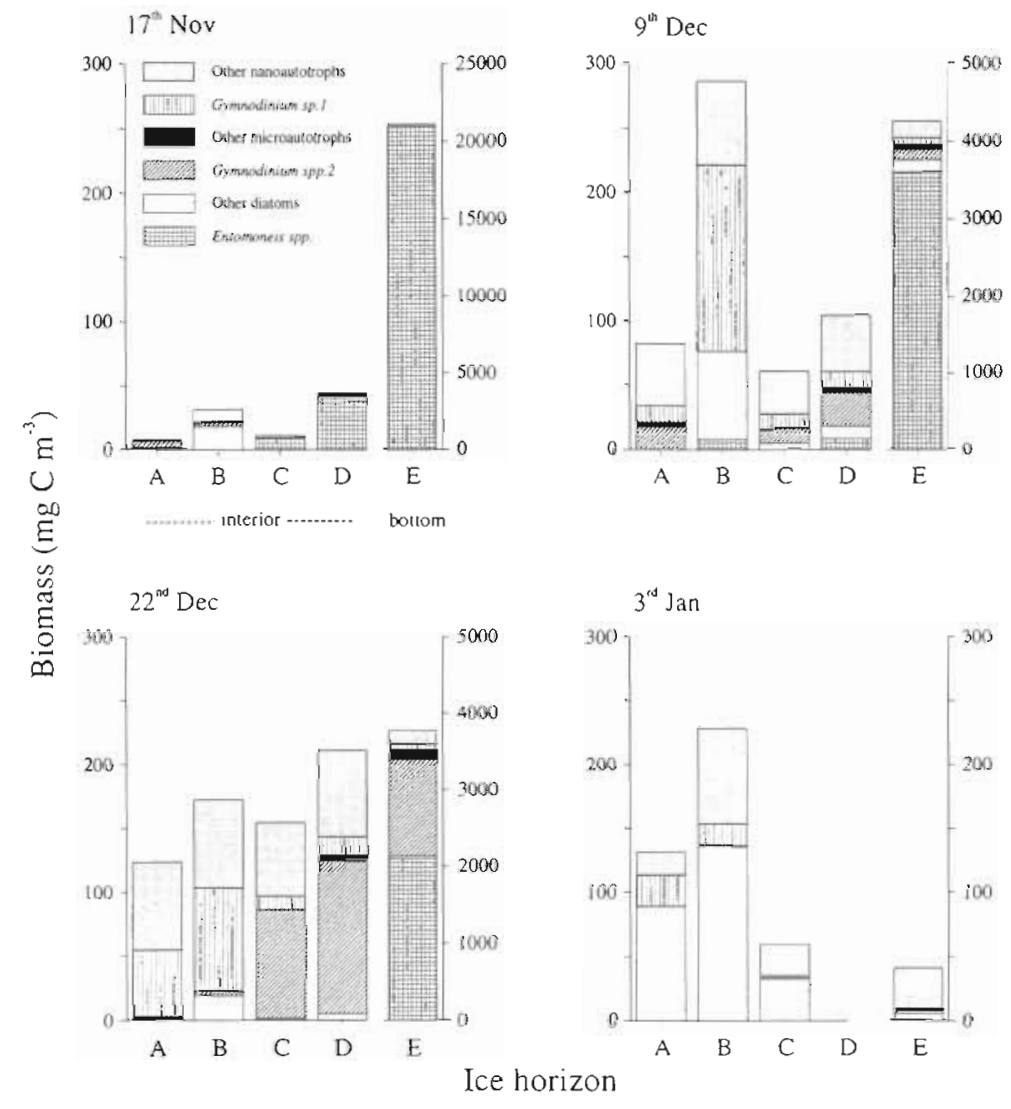

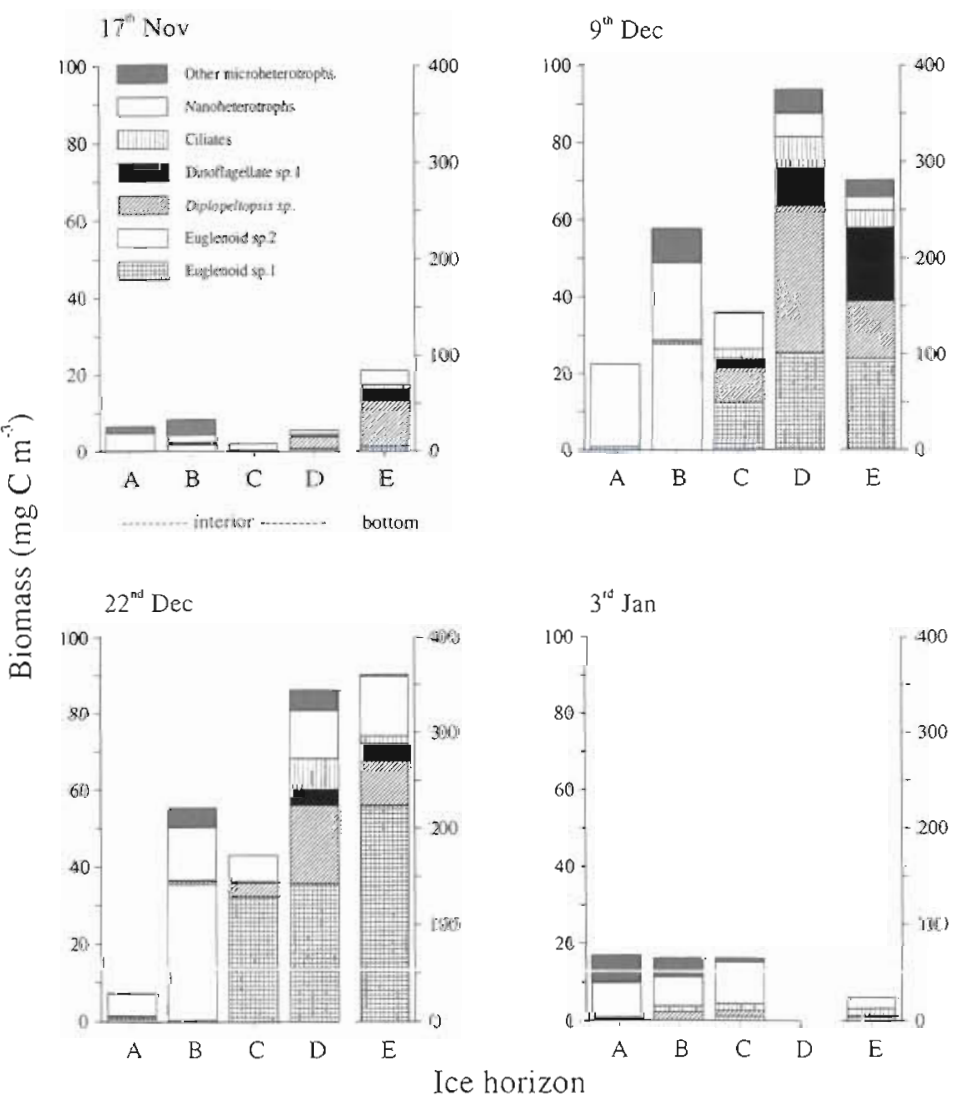

sion. Identification of Diplopeltopsis sp. was based upon the description of thecate structure in Antarctic forms of this genus by Balech (1975). The athecate Dinoflagellate sp.1 was similar to a species described by Buck et al. (1990), in that no flagella or sulcus and cingulum were present and the cells possessed a shallow groove approximately $10 \mu \mathrm{m}$ long on the cell surface. However, cells were smaller and none contained a food vacuole or any evidence of ingested particles. Instead, identification of Dinoflagellate sp.1 was based upon the presence of condensed chromosomes and a lack of chlorophyll autofluoresence.

Internal assemblages were also largely made up of heterotrophic flagellates, including nanoflagellates, euglenoids and dinoflagellates (Fig. 3). Euglenoid sp.2 was of larger

Fig. 3. Mean $(n=3)$ biomass of 7 major categories of heterotrophic protozoan taxa recorded from 5 ice horizons in cores sampled on 17 November 1993, y and 22 December 1993 and 3 January 1994. Details of ice horizon depth are given in Table 1. Note the different scales for Horizon $\mathrm{E}$ 
cell volume than Euglenoid sp.1 (Table 2B). It possessed a ridged pellicle, 2 flagella of unequal length and an obvious ingestion organelle. Ingested cells, particularly those of the small autotrophic Gymnodinium sp.1, were often observed. Euglenoid sp.2 occurred throughout the ice depth but was most abundant in Horizon B where it formed greater than $50 \%$ of the average heterotrophic protozoan biomass during December (Fig. 3). Heterotrophic cells of less than $20 \mu \mathrm{m}$ in length were also abundant and contributed up to $100 \%$ of the heterotrophic biomass in Horizon A.

Although identification of ciliates is uncertain without silver staining procedures, a diverse assemblage of heterotrophic ciliates was found in the land fast sea ice (Table 2B). However, distribution was sporadic and biomass relatively low. Ciliate variety and abundance was highest in the bottom ice where Hypotrich spp.1 and a large unidentified form (Unknown spp.1) contributed most to biomass (Fig. 3).

Bacteria occurred throughout the ice depth. However, biomass varied by several orders of magnitude between horizons ranging from less than $5 \mathrm{mg} \mathrm{C} \mathrm{m}^{-3}$ in Horizon $\mathrm{A}$ to greater than $1400 \mathrm{mg} \mathrm{C} \mathrm{m}^{-3}$ in the bottom ice (Fig. 4, Table 2B). The much higher bacterial biomass found in the bottom ice was attributable to epiphytic bacteria attached to both living and dead Entomoneis spp. cells. Like Entomoneis spp. these bacteria were most abundant in the bottom ice contributing up to $93 \%$ of bacterial (Fig. 4 ) and $33 \%$ of total biomass (Table 2B). Unattached bacteria were considerably

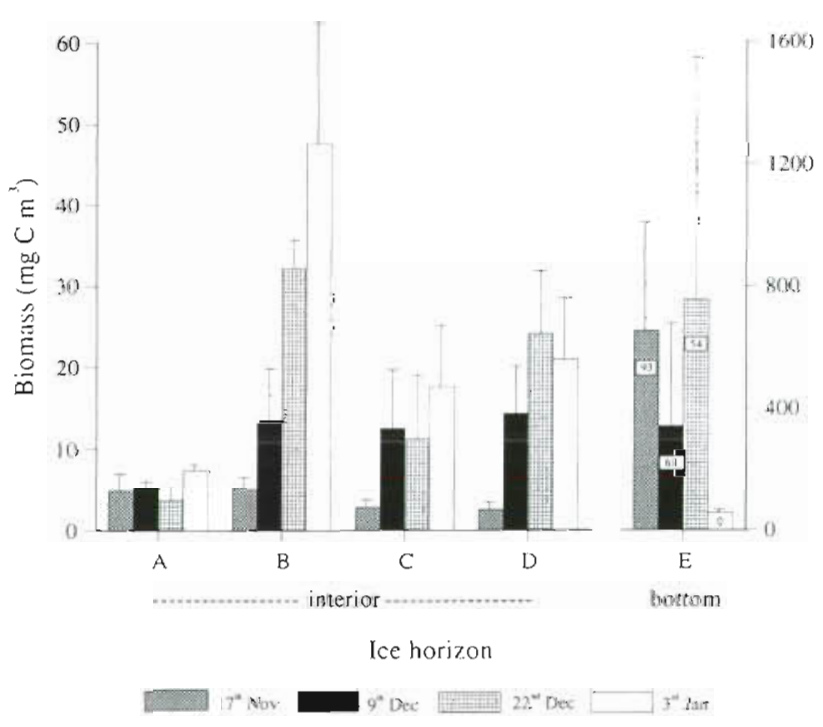

Fig. 4. Mean ( $\mathrm{n}=3$ ) and standard deviation of bacterial biomass recorded from 5 ice horizons in cores collected on 4 dates during the sampling period. Values in the bars are the mean percentage of total bacterial biomass contributed by epiphytic bacteria in the bottom ice on each sampling date. Note the different scale for Horizon E smaller than epiphytic forms havinig a mean cell volume of $0.13 \mu^{3}$ compared to $0.42 \mu \mathrm{m}^{3}$. The maximum biomass of unattached bacteria of $193 \mathrm{mg} \mathrm{C} \mathrm{m}^{-3}$ (Table $2 \mathrm{~B}$ ) recorded in the bottom ice was also considerably lower than that of epiphytic forms

\section{Pack ice}

The composition and vertical distribution of the microbial community in the pack ice sampled on 3 January differed from that obscrved in land fast ice. Maximum biomass was found in Horizons A and B, where diatoms were the main component (Fig. 2). Large diatoms including Corethron criophilum, Chaetoceros sp., Rhizosolenia sp., Eucampia sp. and a variety of centric taxa dominated the biomass of Horizon A (Table 2A). The pennate diatoms Pennale sp. and Synedropsis spp. 3 made up the bulk of the biomass in the Horizon $\mathrm{B}$, contributing a maximum of 172 and $13 \mathrm{mg} \mathrm{C} \mathrm{m}^{-3}$ respectively (Table $2 \mathrm{~A}$, Fig. 2 ). In contrast, the community that inhabited the bottom few centimeters of ice was composed largely of small autotrophic flagellates and contained no cells of Entomoneis spp.

Consistent with the autotrophic community, the abundance of heterotrophic protozoa was relatively low in the ice floe samples (Fig. 3). Small flagellates accounted for the highest proportion of biomass often exceeding $50 \%$ at all ice depths (Fig 3). Interestingly, ciliate biomass was proportionately higher in the ice floe with hypotrich species making up the bulk of the ciliate biomass. No distinction between epiphytic and unattached bacteria occurred in the pack ice due to the absence of Entomoneis spp. However, the mean cell volumes of unattached bacteria found in the pack ice were significantly (analysis of variance, ANOVA, $p<$ 0.001 ) larger than those of the land fast ice. Estimation of the bacterial biomass in the interior of the pack ice also exceeded that found in the fast ice reaching maximum mean values of almost $50 \mathrm{mg} \mathrm{C} \mathrm{m}^{-3}$ in Horizon $B$ (Fig. 4).

\section{Total biomass}

Mean values of total carbon biomass of the microbial community within individual horizons of land fast ice spanned 3 orders of magnitude from 16 to nearly $22000 \mathrm{mg} \mathrm{C} \mathrm{m}^{-3}$ (Table 3). Variability is a characteristic of the taxonomy, distribution and biomass of sea ice microbial communities. Comparisons were made of mean values based on 3 replicate samples taken simultaneously and close together on each date and from the same site on different sampling dates. We 
Table 3. Vertical distribution and integrated values of total carbon biomass and integrated chl a concentration of the sea ice microbial community at Davis Station. Values are means \pm standard deviation of 3 replicate cores per sampling date. Ice cores were sampled from a fixed site except for the drifting ice floe sampled on 3 January 1994 . See Table 1 for information on ice depth and temperature of each horizon

\begin{tabular}{|c|c|c|c|c|c|}
\hline & $\begin{array}{l}\text { Date: } \\
\text { Day: }\end{array}$ & $\begin{array}{c}17 \text { Nov } 93 \\
1\end{array}$ & $\begin{array}{c}9 \text { Dec } 93 \\
23\end{array}$ & $\begin{array}{c}22 \operatorname{Dec} 93 \\
36\end{array}$ & $\begin{array}{c}3 \mathrm{Jan} 94 \\
47\end{array}$ \\
\hline \multicolumn{6}{|c|}{ Biomass ( $\mathrm{mg} \mathrm{C} \mathrm{m}^{-3}$ ) } \\
\hline \multirow[t]{5}{*}{ Ice horizon } & A & $16.3 \pm 4.1^{\mathrm{d}}$ & $94.0 \pm 14.0^{\mathrm{si}}$ & $132.0 \pm 45.3$ & $152.0 \pm 59.2$ \\
\hline & B & $44.8 \pm 8.6$ & $348.5 \pm 92.2$ & $253.7 \pm 34.1$ & $287.9 \pm 53.4$ \\
\hline & $\mathrm{C}$ & $16.2 \pm 3.4$ & $104.2 \pm 9.1$ & $205.8 \pm 55.5$ & $85.2 \pm 40.6^{\mathrm{d}}$ \\
\hline & $\mathrm{D}$ & $51.8 \pm 23.3$ & $205.0 \pm 47.4$ & $308.1 \pm 16.5$ & \\
\hline & E & $21829.0 \pm 8131.5$ & $4869.3 \pm 2595.5$ & $4864.4 \pm 2595.5$ & $112.6 \pm 40.5^{\circ}$ \\
\hline \multicolumn{6}{|c|}{ Integrated biomass ( $\mathrm{mg} \mathrm{C}^{-2}$ ) } \\
\hline \multicolumn{2}{|c|}{ Interior ice } & $58.2 \pm 13.2$ & $391.8 \pm 135.0$ & $385.0 \pm 124.0$ & $309.4 \pm 76.1$ \\
\hline \multicolumn{2}{|c|}{$\%$ autotrophs } & $67.0 \pm 3.3$ & $76.9 \pm 2.8$ & $74.3 \pm 3.1$ & $78.3 \pm 4.5$ \\
\hline \multicolumn{2}{|c|}{$\%$ heterotrophic protozoa } & $19.2 \pm 5.4$ & $17.8 \pm 2.9$ & $16.0 \pm 6.9$ & $5.7 \pm 1.3$ \\
\hline \multicolumn{2}{|c|}{$\%$ bacteria } & $13.8 \pm 2.4$ & $5.3 \pm 0.3$ & $9.7 \pm 3.8$ & $16.0 \pm 5.7$ \\
\hline \multicolumn{2}{|l|}{ Bottom ice } & $1091.5 \pm 704.2$ & $243.5 \pm 202.9$ & $243.2 \pm 224.8$ & $5.6 \pm 2.9$ \\
\hline \multicolumn{2}{|c|}{$\%$ autotrophs } & $95.4 \pm 3.4$ & $83.4 \pm 9.0$ & $77.3+19.7$ & $33.5 \pm 14.1$ \\
\hline \multicolumn{2}{|c|}{$\%$ heterotrophic protozoa } & $0.7 \pm 0.8$ & $11.1 \pm 12.3$ & $6.9 \pm 0.6$ & $12.3 \pm 4.9$ \\
\hline \multicolumn{2}{|c|}{$\%$ bacteria } & $3.9 \pm 2.6$ & $5.5 \pm 3.3$ & $15.8 \pm 19.1$ & $54.2 \pm 18.9$ \\
\hline \multicolumn{2}{|l|}{ Total } & $1150 \pm 713$ & $635 \pm 132$ & $628 \pm 347$ & $315 \pm 75$ \\
\hline \multicolumn{6}{|c|}{ Integrated chl a (mg chl a m$\left.{ }^{-2}\right)$} \\
\hline \multicolumn{2}{|c|}{ Interior ice } & $3.6 \pm 2.5$ & $5.9 \pm 1.8$ & $2.9 \pm 1.8$ & $5.4 \pm 3.3$ \\
\hline \multicolumn{2}{|l|}{ Bottom ice } & $69.4 \pm 71.4$ & $7.7 \pm 10.5$ & $6.2 \pm 6.6$ & $0.2 \pm 0.0$ \\
\hline \multicolumn{2}{|l|}{ Total } & $73.1 \pm 69.9$ & $13.6 \pm 12.3$ & $9.1 \pm 5.4$ & $5.5 \pm 3.3$ \\
\hline \multicolumn{6}{|c|}{ Autotrophic carbon:chl $a$} \\
\hline \multicolumn{2}{|l|}{${ }^{\mathrm{a}} \mathrm{n}=2$} & & & & \\
\hline
\end{tabular}

believe our sets of replicate samples fairly represent the microbial communities at this site. A 2-way ANOVA with replication (Sokal \& Rohlf 1973) was carried out on the total biomass of autotrophs, heterotrophic protozoa and bacteria measured in each horizon and confirmed that the data illustrated significant seasonal and vertical changes in the community and were not merely a consequence of variation between replicate samples (Table 4) The distinction in taxonomic composition, carbon biomass and chl a concentration between the interior Horizons $\mathrm{A}, \mathrm{B}, \mathrm{C}$ and $D$ and the bottom ice of Horizon E justified a division of the 2 communities.

When integrated throughout the respective ice depths, the difference between the total biomass (mg $\mathrm{C} \mathrm{m}^{-2}$ ) of bottom and interior assemblages is less marked, with between 38 and $95 \%$ of the total integrated biomass attributable to organisms within the bottom $5 \mathrm{~cm}$ of fast ice (Table 3). In the pack ice values measured within interior horizons were comparable to those of the fast ice, ranging from 85 to $288 \mathrm{mg}$ $\mathrm{C} \mathrm{m}^{-3}$, however, mean integrated biomass of the bottom ice was more than 40 times lower than for fast ice (Table 3)
Table 4. Spatial and temporal variability of the ice microbial community: summary of results of a 2-way ANOVA with replication (Sokal \& Rohlf 1.973) on the autotrophic, heterotrophic and bacteria biomass in individual horizons. Values of biomass from only the land fast ice are used. ANOVA was carned out on $\log _{10}$-transformed data

\begin{tabular}{|lrrr|}
\hline Source of variation & df & MS & $F$ \\
\hline Autotrophs & & & \\
$\quad$ Among dates & 2 & 1.41 & $17.47, \mathrm{p}<0.001$ \\
$\quad$ Among horizons & 4 & 6.82 & $84.50, \mathrm{p}<0.001$ \\
$\quad$ Interaction & 8 & 0.63 & $7.83, \mathrm{p}<0.001$ \\
$\quad$ Between replicates & 30 & 0.08 & \\
$\quad$ Total & 44 & & \\
Heterotrophic protists & & & \\
$\quad$ Among dates & 2 & 3.43 & $30.77, \mathrm{p}<0.001$ \\
Among horizons & 4 & 2.44 & $21.95, \mathrm{p}<0.001$ \\
Interaction & 8 & 0.24 & $2.11, \mathrm{p}>0.05$ \\
$\quad$ Between replicates & 30 & 0.11 & \\
$\quad$ Total & 44 & & \\
Unattached bacteria & & & \\
$\quad$ Among dates & 2 & 1.19 & $17.11, \mathrm{p}<0.001$ \\
Amond horizons & 4 & 1.35 & $19.34, \mathrm{p}<0.001$ \\
Interaction & 8 & 0.18 & $2.63, \mathrm{p}<0.05$ \\
Between replicates & 30 & 0.07 & \\
Total & 44 & & \\
\hline
\end{tabular}




\section{Seasonal change}

Total microbial biomass integrated throughout the ice depth (interior plus bottom) declined from a mean of $1150 \mathrm{mg} \mathrm{C} \mathrm{m}^{-2}$ on 17 November to 635 and $628 \mathrm{mg}$ $\mathrm{C} \mathrm{m}^{-2}$ on 9 and 22 December respectively (Table 3), indicating a seasonal decline in fast-ice community biomass during the study period. Mean integrated microbial biomass within the ice floe samples was lower than that of the fast ice at $315 \mathrm{mg} \mathrm{C} \mathrm{m}^{-2}$.

The decline in total microbial biomass observed in the bottom community of fast ice was largely attributable to a decline in autotrophs (Fig. 5). In particular, the mean biomass of Entomoneis spp. decreased from over $2 \times 10^{4} \mathrm{mg} \mathrm{C} \mathrm{m}^{-3}$ on 17 November to $2 \times 10^{3} \mathrm{mg} \mathrm{C}$ $\mathrm{m}^{-3}$ on 22 December (Fig. 2). As a result, the mean integrated autotrophic biomass and chl a concentration declined from 1041 to $188 \mathrm{mg} \mathrm{C} \mathrm{m}^{-2}$ and 69 to $6 \mathrm{mg}$ chl a $\mathrm{m}^{-2}$ during the same period. Conversely, the biomass of heterotrophic protozoa in the bottom ice more than trebled, largely due to the increase in biomass of Euglenoid sp.1, Dinoflagellate sp.1 and heterotrophic
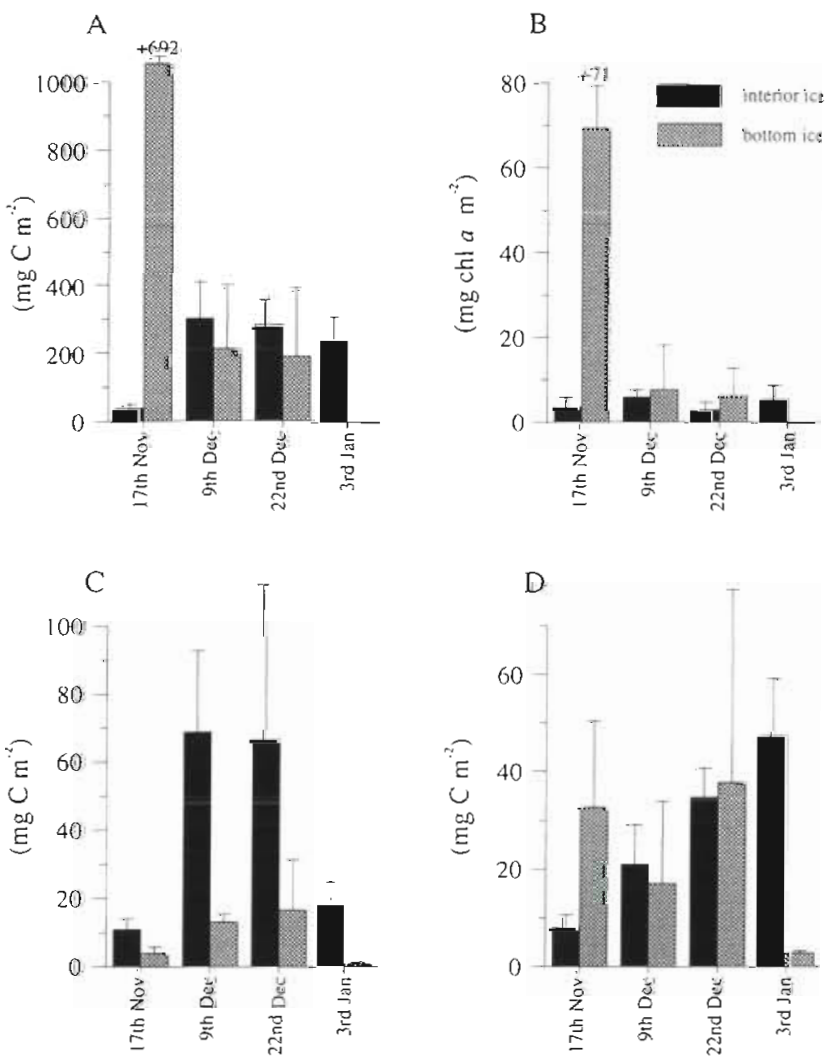

Fig. 5. Temporal change in the integrated biomass of $(A)$ autotrophs, (B) chl a, (C) heterotrophic protozoa and (D) bacteria in the interior and bottom ice. Values are mean $(n=3)$ and standard deviation of 3 replicate cores on each sampling date. Note that samples collected on 3 January were from a drifting ice floe, not the fixed land fast site sampled on the other 3 dates nanoflagellates (Fig. 3). Variation in bacterial biomass was dependent on the presence of epiphytic forms that colonised both live and dead cells of Entomoneis spp. However, the large decrease in biomass of Entomoneis spp. between 17 November and 22 December was not matched by a reduction in bacterial biomass (Fig 5) and the mean percentage of bacteria increased from 3.9 to $15.8 \%$ of the total biomass (Table 3 )

In contrast to the bottom ice, an increase in total integrated biomass from $58 \mathrm{mg} \mathrm{C} \mathrm{m} \mathrm{Cm}^{-2}$ on 17 November to $392 \mathrm{mg} \mathrm{C} \mathrm{m}{ }^{-2}$ in December occurred in the interior ice (Table 3). This was a consequence of increases in both autotrophic and heterotrophic fractions, the relative percentages of which remained almost constant throughout the period (Table 3). An increase in biomass of Gymnodinium sp.1 and other nanoautotrophs contributed most to the change in autotrophic biomass in the interior ice (Fig. 2). An increase in all components of the heterolrophic biomass took place between 17 November and 9 December (Fig. 3). Bacterial biomass also increased throughout the interior ice and throughout the sampling period (Figs. 4 \& 5).

\section{Photosynthetic rate measurements}

Photosynthetic rate measurements were carried out on 2 dates midway between the major ice sampling dates. Mean production rates in the bottom ice based on measurements of ${ }^{14} \mathrm{C}$ incorporation were 637 and $94 \mathrm{mg} \mathrm{C} \mathrm{m} \mathrm{m}^{-3} \mathrm{~d}^{-1}$ on 29 November and 16 December respectively. When normalised to the chl a concentration in each sample, ${ }^{14} \mathrm{C}$ incorporation rates gave mean assimilation values on 29 November and 16 December of 18.2 and $8.3 \mathrm{mg} \mathrm{C} \mathrm{mg}^{-1} \mathrm{chl} \mathrm{a} \mathrm{d} \mathrm{d}^{-1}$, respectively (Table 5).

Table 5. Photosynthetic rate estimates (means \pm SD) from the measurement of ${ }^{14} \mathrm{C}$ incorporation in bottom ice samples

\begin{tabular}{|lccc|}
\hline Date & $\begin{array}{c}\text { Chl d } \\
\left(\mathrm{mg} \mathrm{m}^{-3}\right)\end{array}$ & $\begin{array}{c}\text { Specific carbon } \\
\text { incorporation } \\
\left(\mathrm{mg} \mathrm{mg}^{-1} \mathrm{chl} \mathrm{d}^{-1}\right)\end{array}$ & $\begin{array}{c}\text { Production } \\
\left(\mathrm{mg} \mathrm{C} \mathrm{m}^{-3} \mathrm{~d}^{-1}\right)\end{array}$ \\
\hline $29 \mathrm{Nov}$ & $36.9 \pm 9.0$ & $18.2 \pm 4.2$ & $637 \pm 117$ \\
$16 \mathrm{Dec}$ & $14.9 \pm 15.7$ & $8.3 \pm 3.3$ & $94 \pm 64$ \\
\hline
\end{tabular}

\section{DISCUSSION}

\section{Community composition}

The coastal sea ice examined in this study provided a habitat for abundant and dynamic microbial communities in both the interior and bottom horizons. 


\section{Autotrophs}

This and previous studies in the nearshore ice of East Antarctica have demonstrated an active autotrophic community of high biomass inhabiting the bottom few centimeters of fast ice during spring and summer (Hoshiai 1977, McConville \& Wetherbee 1983, McConville et al. 1985, Perrin et al. 1987, Watanabe \& Satoh 1987). McConville \& Wetherbee (1983) reported a bottom ice community dominated by colonial pennate diatoms in land fast ice near all 3 Australian Antarctic stations of Davis, Casey $\left(66^{\circ} 17^{\prime} \mathrm{S}, 110^{\circ} 30^{\prime} \mathrm{E}\right)$ and Mawson (67 $36^{\prime} \mathrm{S}, 62^{\circ} 53^{\prime} \mathrm{E}$ ). Similar communities have been described in the vicinity of the Japanese station of Syowa $\left(69^{\circ} 00^{\prime} \mathrm{S}, 39^{\circ} 35^{\prime} \mathrm{E}\right)$ (Hoshiai 1977. Watanabe et al. 1990). In all cases, including the present study, the peak standing crop occurs in November and declines thereafter as water and ice temperatures rise and insolation increases, although at Davis the overall ice thickness did not decrease at this time. The reason for the rapid decrease in bottom community biomass is unclear. McConville \& Wetherbee (1983) reported that a low salinity layer occurs just below the ice at this time of year and may contribute to the decline. It was established that large numbers of metazoan grazers were present under the ice, but it is unlikely that grazing accounts for the rapid decline in biomass, and here as elsewhere it appears that most of the diatom community becomes detached into the water beneath (see below).

Comprehensive studies of the bottom ice autotrophic communities of annual and multi-year ice have taken place in McMurdo Sound (approximately $78^{\circ} \mathrm{S}, 165^{\circ} \mathrm{E}$ ) (Palmisano \& Sullivan 1983, Grossi et al. 1984, Grossi \& Sullivan 1985, Lizotte \& Sullivan 1992, Arrigo et al. 1993b). The bottom few centimeters of congelation ice contain a spring/summer community of similar taxonomy and biomass to that observed off East Antarctica. However, a layer of platelet ice crystals colonised by pennate diatoms and greatly exceeding in biomass the overlying congelation ice communities often develops in McMurdo Sound (Grossi et al. 1987, Arrigo et al. 1993b) Platelet ice layers form in areas where sea water is supercooled at depth by contact with the continental ice shelf (Foldvik \& Kvinge 1977, Dieckmann et al. 1986) and therefore bottom ice platelet layers are unlikely to be found in the relatively shallow coastal regions in the vicinity of land as occurs off Davis and Syowa Stations. Observations using SCUBA equipment (McConville et al. 1985) and our underwater video observations confirmed the lack of a platelet layer in the Davis region.

viatom communities of various fast ice habitats have been described at lower latitudes close to the shore of Signy Island $\left(60^{\circ} 42^{\prime} \mathrm{S}, 45^{\circ} 36^{\prime} \mathrm{W}\right)$ and Anvers Island $\left(64^{\circ} 46^{\prime} \mathrm{S}, 64^{\circ} 06^{\prime} \mathrm{W}\right.$ ) (Whitaker 1977, Krebs et al 1987). Particularly high concentrations of chl a of 236 and $3991 \mathrm{mg} \mathrm{m}^{-2}$ respectively were attributed to the diatom Navicula glaciei at these 2 sites.

Fewer studies have examined the interior assemblages of land fast ice. Similar vertical profiles of chl a to those recorded in this study have been reported for fast ice in McMurdo Sound (Palmisano \& Sullivan 1983), close to Syowa Station (Hoshiai 1977) and in fast ice along the ice shelf that forms the eastern coast of the Weddell Sea (Spindler \& Dieckmann 1986). In all 3 locations the chl a concentrations found in the interior ice were several orders of magnitude lower than in the bottom few centimeters of ice; although a peak of chl a concentration in the interior ice was observed during winter at Syowa Station and was attributed to the incorporation of an autumnal bottom ice diatom bloom as the ice depth increased (Hoshiai 1977). Stoecker et al. (1992) described an autotrophic community inhabiting the interior of fast ice in McMurdo Sound with a similar taxonomic composition to that found in this study. A small dinoflagellate resembling Gymnodinium sp.1 reached an abundance of 2796 cells $\mathrm{ml}^{-1}$ of brine and photosynthetic dinoflagellates and their cysts comprised over $80 \%$ of the autotrophic biomass in December. Chl a values extrapolated from concentrations in brine samples from the upper $50 \mathrm{~cm}$ of fast ice in McMurdo Sound increased during December from 0.07 to $0.88 \mathrm{mg} \mathrm{m}^{-3}$ of ice (Stoecker et al. 1992). This is similar to the almost 7 -fold increase in integrated biomass of the interior ice communities at Davis during early summer. Hoshiai (1977) also reported the development of a dinoflagellate population in the interior of the fast ice off Syowa in December. This suggests that an actively growing interior ice assemblage dominated by autotrophic dinoflagellate species may be widespread in fast ice around Antarctica.

\section{Heterotrophic protozoa}

It is becoming increasingly clear that a wide variety and in some cases a high abundance of heterotrophic protozoa inhabit sea ice. Estimates of the mean total integrated biomass of heterotrophic protists in the land fast ice at O'Gorman Rocks increased from 19 to $97 \mathrm{mg}$ $\mathrm{C} \mathrm{m}^{-2}$ from November to December. Interior assemblages contributed the major part of the integrated biomass. However, maximum concentrations occurred in the bottom ice with mean values for heterotrophic protozoan biomass approaching $300 \mathrm{mg} \mathrm{C} \mathrm{m}^{-3}$ during December. In the pack ice of the Weddell Sea estimates of the integrated biomass of heterotrophic protozoa were generally less than half the maximum value 
of $75 \mathrm{mg} \mathrm{C} \mathrm{m}^{-2}$ (Garrison \& Close 1993). Maximum concentrations of heterotrophic protozoa were found in the surface layers of pack ice reaching $160 \mathrm{mg} \mathrm{C} \mathrm{m}{ }^{-3}$ and corresponding with high autotrophic biomass (Garrison \& Buck 1991). In brine samples from the upper $50 \mathrm{~cm}$ of fast ice of McMurdo Sound the average biomass of non-photosynthetic protists ranged from 0.2 to $27.6 \mathrm{mg} \mathrm{C} \mathrm{m}^{-3}$ varying with location and date (Stoecker et al. 1993). Brine samples represented an approximately 4 -fold concentration of actual ice values at the time of sampling (Stoecker et al. 1992), suggesting similar or lower values than were recorded in Horizon A of ice offshore from Davis. The taxonomic composition of heterotrophic protozoa was similar in the pack ice of the Weddell Sea and the upper fast ice of McMurdo Sound to that found in coastal sea ice examined in East Antarctica in the present study.

Heterotrophic nanoflagellates appear to be major contributors to the biomass in both pack and fast ice. Choanoflagellates were noticeably abundant in the surface layer assemblages of the summer pack ice in the Weddell Sea (Garrison \& Buck 1991). The present study and samples collected in the upper ice brine samples from McMurdo Sound (Stoecker et al. 1993) suggest that choanoflagellates are not as important a part of the heterotrophic community in land fast ice. On the other hand, Cryothecomonas spp. appear to be ubiquitous in Antarctic sea ice (Garrison \& Buck 1989, Thomsen et al. 1991, Garrison \& Close 1993, Stoecker et al. 1993, present study).

The presence of heterotrophic euglenoids in sea ice has been recorded previously but they were not regarded as a major component of the heterotrophic biomass (Garrison \& Buck 1989). In this study Euglenoid sp. 1 and Euglenoid sp 2 at certain times each contributed greater than $50 \%$ of the biomass of heterotrophic protozoa in the bottom and interior horizons. Heterotrophic dinoflagellates were found throughout the ice depth and athecate and thecate forms contributed a similar high proportion of the heterotrophic biomass. Heterotrophic dinoflagellates, especially athecate forms, were a common component of the ice community in both the Weddell Sea (Garrison \& Buck 1989. Mathot et al. 1991) and fast ice of McMurdo Sound (Stoecker et al. 1993). Pack ice assemblages contained an unusual phagotrophic dinoflagellate that is able to engulf pennate diatoms and produces detrital pe:llets (Buck et al. 1990). Dinoflagellate sp.1 observed in this study had several characteristics in common with the phagotrophic dinoflagellate described by Buck et al. (1990), but showed no evidence of being phagotrophic (see 'Results') The large phagotrophic dinoflagellate Polykrikos sp. commonly found in brine samples from McMurdo Sound (Stoecker et al. 1993) was not observed in this study.
More than 20 ciliate taxa have been identified using silver staining techniques from the pack ice of the Weddell Sea (Corliss \& Snyder 1986). Stoecker et al. (1993) also reported a diverse ciliate assemblage in the upper $50 \mathrm{~cm}$ of fast ice in McMurdo Sound. Ciliates contributed a major part of the biomass of heterotrophic protists in both the Weddell Sea pack ice (Garrison \& Buck 1989) and the fast ice of McMurdo Sound (Stoecker et al. 1993). Highest ciliate biomass in the present study occurred in the lower horizons reaching values of $10 \mathrm{mg} \mathrm{C} \mathrm{m}^{-3}$ and always $<10 \%$ of heterotrophic protozoan biomass. In the upper ice horizons corresponding to the brine sampled by Stoecker et al. (1993) ciliate biomass rarely exceeded $2 \mathrm{mg} \mathrm{C} \mathrm{m}{ }^{-3}$ and contributed an even lower proportion of heterotrophic protozoan biomass. Brine volume was calculated to be approximately $25 \%$ ice volume in the upper $50 \mathrm{~cm}$ of fast ice in McMurdo Sound in late December (Stoecker et al. 1992) which would make estimates of ciliate biomass comparable to those found offshore from Davis. However, in both cases they are considerably lower than values reported from surface layers of pack ice where total ciliate biomass exceeded $100 \mathrm{mg} \mathrm{C} \mathrm{m}^{-3}$ on occasions (Garrison \& Buck 1991). This is despite the fact that the volume to carbon conversion factor used by Garrison \& Buck (1989) was less than half that used by Stoecker et al. (1993) and in the present study.

Foraminifera were not found in the sea ice examined in this study or reported to occur in the upper fast ice of McMurdo Sound (Stoecker et al. 1993). This confirms their scarcity in congelation ice

\section{Bacteria}

The mean standing crop of bacteria in sea ice offshore from Davis was 40 to $70 \mathrm{mg} \mathrm{C} \mathrm{m}^{-2}$ (Fig. 5). This is higher than values reported for McMurdo Sound where a mean standing crop of $9.8 \mathrm{mg} \mathrm{C} \mathrm{m}^{-2}$ was recorded by Sullivan \& Palmisano (1984). However, the cell volume to carbon conversion factor of $0.4 \mathrm{pg} \mathrm{C}$ $\mu \mathrm{m}^{-3}$ (Bjørnsen \& Kuparinen 1991) used in the present study is 4 times greater than that used by Sullivan \& Palmisano (1984) and explains some of the difference. The vertical profile of bacterial biomass in fast ice at $O^{\prime}$ Gorman Rocks is similar to that described in McMurdo Sound (Sullivan \& Palmisano 1984). In both cases the presence of epiphytic bacteria in the bottom ice contributes to the large variation in bacterial biomass between bottom and interior assemblages. McConville \& Wetherbee (1983) also reported high concentrations of epiphytic bacteria attached to Entomoneis spp. and to the mucilage sheaths of the diatom Amphipleura sp. in bottom ice near Casey $\left(66^{\circ} 17^{\prime} \mathrm{S}\right.$, 
$110^{\circ} 30^{\prime} \mathrm{E}$ ). At least $65 \%$ of epiphytic bacteria occurred on diatoms of the genus Amphiprora (= Entomoneis spp. in the present study) in the bottom ice of McMurdo Sound (Grossi et al. 1984). A commensal or mutualistic interaction between the epiphytic bacteria of Entomoneis spp. and their host has been suggested by both Sullivan \& Palmisano (1984) and Grossi et al. (1984). A similar relationship occurs in the bottom jce of Barrow Strait in the Canadian Arctic where the dominant diatom Nitzschia frigida is the preferred host of epiphytic bacteria (Smith et al. 1989). Epiphytic bacteria attached to Entomoneis spp. contributed mean percentages of between 54 and $93 \%$ of bacterial biomass in the bottom ice samples in the present study but their biomass was highly variable. An increase in free living bacterial biomass occurred throughout the ice depth between November and December in the fast ice offshore from Davis. Integrated biomass of the interior ice matched that of the bottom ice assemblages at greater than $30 \mathrm{mg} \mathrm{C} \mathrm{m} \mathrm{m}^{-2}$ by 22 December, illustrating that an important and active bacterial community exists in the interior of land fast ice.

\section{Production and trophic interactions}

Early summer at Davis Station was a period of increasing insolation culminating in a general increase in temperature throughout the depth of sea ice and a reduction in snow cover. These are conditions that would be expected to promote microbial production in sea ice. However, the fate of the bottom and interior ice communities differed markedly during this period.

Primary production of sea ice microalgae has been estimated in a number of ways including incorporation rate of ${ }^{14} \mathrm{C}$ and accumulation of biomass. Comparisons of the 2 methods reveal up to a 10 -fold greater estimate when rates of incorporation of ${ }^{14} \mathrm{C}$ are compared to estimates made from the accumulation of biomass in bottom ice communities of McMurdo Sound (Grossi et al. 1987). Possible causes of this discrepancy are loss of biomass to the water column and losses due to grazing by metazoans and protozoans (Grossi et al. 1987). McConville et al. (1985) observed sea ice algal fragments that had fallen out of the ice into the water column at Davis. Using underwater video in the present study, large numbers of amphipods were observed on the underside of the ice. A minimum estimate of the biomass of the bottom community that enters the water column or is grazed can be obtained from the decline in biomass between sampling dates. A decline of $838 \mathrm{mg} \mathrm{C} \mathrm{m} \mathrm{m}^{-2}$ occurred between 17 November and 9 December

A more realistic estimate of the carbon biomass produced in the bottom ice can be calculated using mea- surements of primary production of bottom ice communities. In situ incubations of the bottom ice community with ${ }^{14} \mathrm{C}$, recorded during the middle of the day at Davis, gave a mean hourly assimilation number of $1.3 \mathrm{mg} \mathrm{C} \mathrm{mg}^{-1} \mathrm{chl} \mathrm{a} \mathrm{h}^{-1}$ in December for samples containing 2.7 to $15.6 \mathrm{mg} \mathrm{chl} \mathrm{a} \mathrm{m}^{-2}$ (McConville et al. 1985). In situ $24 \mathrm{~h}^{14} \mathrm{C}$ incubations of intact bottom ice samples in the present study indicated similar daily assimilation numbers of 18.2 and $8.3 \mathrm{mg} \mathrm{C} \mathrm{mg}^{-1} \mathrm{chl} \mathrm{a}$ $\mathrm{d}^{-1}$ on 29 November and 16 December respectively. Assuming the majority of the bottom ice community biomass fell into the water column soon after 17 November then the chl a concentration in bottom ice on 9 December may be used as a minimum value to relate assimilation number to production. This would give an estimated production rate of $140 \mathrm{mg} \mathrm{C} \mathrm{d}^{-1}$ and a total production of $3.089 \mathrm{~g} \mathrm{C} \mathrm{m}^{-2}$ in the bottom ice during the period 17 November to 9 December. Following the same assumptions, estimated production during the period 9 to 22 December would equal a total of $670 \mathrm{mg} \mathrm{C} \mathrm{m}{ }^{-2}$ at a rate of $51.2 \mathrm{mg} \mathrm{C} \mathrm{m} \mathrm{Cd}^{-1}$. When combined with the decline in biomass of the bottom ice community this would suggest that a minimum quantity of $4.6 \mathrm{~g} \mathrm{C} \mathrm{m}^{-2}$ of primary production from the bottom ice community entered the water column or was consumed by heterotrophs following the peak of algal biomass in November.

The increase in the total biomass of heterotrophic protozoa in the bottom ice represented a minimum estimate of instantaneous growth rate of $0.054 \mathrm{~d}^{-1}$ and $0.018 \mathrm{~d}^{-1}$ in the 2 time intervals. These values obviously ignore the probability of migration into or from the bottom ice and the change in population biomass of heterotrophs involved a complex interaction of increase and decrease in different taxa. Alteration in biomass of the bottom ice bacterial population comprised largely of epiphytic forms would be expected to coincide with the decline in biomass of Entomoneis spp. However, despite the large variability between replicates and an increase in unattached bacterial biomass during the sampling period, the greater proportion of epiphytic bacteria relative to Entomoneis spp. biomass indicates increased colonisation of Entomoneis spp. cells by 22 December.

Measurements of ${ }^{14} \mathrm{C}$ incorporation were not carried out for interior fast ice communities in this study. Instead, an estimate of primary production can be made from the accumulation of biomass in the interior ice between sampling dates. This assumes no migration of autotrophic biomass into or from the bottom ice and no grazing loss. Integrated autotrophic biomass increased by $280 \mathrm{mg} \mathrm{C} \mathrm{m}^{-2}$ in the interinr accemblagge between 17 November and 9 December representing an intrinsic rate of growth of the autotrophic population of $0.095 \mathrm{~d}^{-1}$. The integrated biomass of hetero- 
trophic protozoa and bacteria also increased during this period and, if the same assumptions are made, showed population growth rates of 0.083 and $0.043 \mathrm{~d}^{-1}$ respectively. Net autotrophic production (gross production - respiratory losses) can be re-evaluated when growth of the heterotrophic component is taken into account. Among many variables, the incorporation efficiency of carbon by both bacteria and heterotrophic protozoa will depend upon utilisability of the organic matter or food quality (Azam et al. 1983, Caron 1991) Gross growth efficiencies of heterotrophic protozoa may vary between 2 and $82 \%$ (Caron \& Goldman 1990). In the North Atlantic the transfer efficiency of carbon biomass between phytoplankton and heterotrophic protozoa was estimated at 30 to $100 \%$, increasing with a decrease in the proportion of phytoplankton grazed (Burkill et al. 1993). Estimates of the gross growth efficiency of bacteria are equally variable. Bacterial carbon growth yields of between 40 and $38 \%$ have been estimated in cultures established from Weddell and Scotia Sea waters (Bjørnsen \& Kuparinen 1991). If the carbon conversion efficiency of heterotrophic protozoa and bacteria was $40 \%$ in the present study and autotrophic production was the only food source available, then the autotrophic biomass consumed by these 2 groups would be 146 and $32 \mathrm{mg} \mathrm{C}$ $\mathrm{m}^{-2}$ respectively. This would raise the value of net primary production from 280 to $457 \mathrm{mg} \mathrm{C} \mathrm{m}^{-2}$, representing a growth rate of $0.115 \mathrm{~d}^{-1}$. Continuing this theme, the proportion of interior ice net primary production consumed during this period by heterotrophic protozoa and bacteria can be estimated at 32 and $7 \%$ respectively. The slight decrease in mean integrated autotrophic biomass that occurred between 9 and 22 December was due to a decline in the mean autotrophic biomass in Horizon B. In all other interior horizons the autotrophic biomass continued to grow, suggesting that the decline in Horizon $B$ may have been due to grazing losses or migration within the ice rather than to a decrease in photosynthetic capacity. Although these calculations involve gross extrapolation of the available data, they provide an invaluable estimate of the summer primary production in interior ice and a rare illustration of the importance of both heterotrophic protozoa and bacteria in sea ice.

Estimates of the specific growth rates $(\mu)$ of the major heterotrophic components of the sea ice community were calculated from changes in specific integrated biomass between sampling dates $\left[\mu=\left(\ln C_{1}-\ln C_{2}\right) /\left(t_{2}-\right.\right.$ $t_{1}$ ), where $C$ is biomass at time $t$ ] (Table 6 ). This equation assumes exponential growth, no mortality due to predation and no migration out of or into the ice. Net growth rates of heterotrophic protozoa estimated in the present study ranged between $0.168 \mathrm{~d}^{-1}$ for Euglenoid sp. 1 and $0.050 \mathrm{~d}^{-1}$ for the heterotrophic nanoflagellate population in the period between 17 November and 9 December (Table 6); only the euglenoids continued to show net growth bctwcen 9 December and 22 December. When the low temperature (less than $-1.9^{\circ} \mathrm{C}$ ) and possible losses due to grazing (particularly for the nanoflagellates) or migration to the water column are considered, these values are tenable.

Previous studies of bacterial growth in bottom ice indicate a faster rate of growth for epiphytic than for unattached forms (Grossi et al. 1984, Kottmeier et al. 1987, Smith et al. 1989). However, these measurements were carried out during the bloom in bottom ice autotrophic production. The sampling period of this study coincided with a decline in the bottom ice autotrophic biomass that may explain the high variability of bottom ice bacterial biomass (Fig. 4). The growth rates $(\mu)$ of unattached bacteria integrated throughout the ice depth $\left(0.040\right.$ to $0.046 \mathrm{~d}^{-1}$; Table 6) are comparable to growth rates measured in the bottom of congelation ice in McMurdo Sound from net accumulation of biomass $\left(0.03\right.$ to $0.09 \mathrm{~d}^{-1}$; Grossi et al 1984 ) and thymidine incorporation $\left(0.007\right.$ to $0.200 \mathrm{~d}^{-1}$ Kottmeier et al. 1987). Similar estimates of bacterial

Table 6. Temporal change in biomass of indrvidual heterotrophic protist types and bacteria. Biomass values are mean \pm SD of integrated biomass of 3 replicate cores. Growth rates are net rate of growth calculated from the change in integrated biomass between sampling dates

\begin{tabular}{|c|c|c|c|c|c|}
\hline \multirow{3}{*}{$\begin{array}{l}\text { Date: } \\
\text { Days: }\end{array}$} & \multicolumn{3}{|c|}{ Biomass ( $\mathrm{mg} \mathrm{C} \mathrm{m} \mathrm{m}^{-2}$ ) } & \multicolumn{2}{|c|}{ Growth rate $\left(\mu, \mathrm{d}^{-1}\right)$} \\
\hline & 17 Nov 93 & 9 Dec 93 & 22 Dec 93 & & \\
\hline & 1 & 23 & 36 & 1 to 23 & 23 to 36 \\
\hline Euglenoid sp.1 & $0.33 \pm 0.07$ & $13.08 \pm 7.28$ & $29.44 \pm 16.71$ & 0.168 & 0.062 \\
\hline Euglenoid sp.2 & $1.38 \pm 0.89$ & $23.25 \pm 14.82$ & $28.07 \pm 24.87$ & 0.128 & 0.015 \\
\hline Diplopeltopsis sp. & $3.06 \pm 1.15$ & $11.82 \pm 8.47$ & $6.00 \pm 2.66$ & 0.061 & -0.052 \\
\hline Dinoflagellate sp. 1 & $0.76 \pm 0.25$ & $5.96 \pm 2.74$ & $1.72 \pm 1.41$ & 0.094 & -0.095 \\
\hline Nanoflagellates & $5.62 \pm 0.60$ & $16.79 \pm 4.84$ & $11.22 \pm 2.17$ & 0.050 & -0.031 \\
\hline Unattached bacteria & $9.50 \pm 3.74$ & $22.86 \pm 7.83$ & $41.32 \pm 2.71$ & 0.040 & 0.046 \\
\hline Epiphytic bacteria & $31.01 \pm 18.85$ & $15.25 \pm 16.08$ & $31.10 \pm 36.13$ & -0.032 & 0.055 \\
\hline
\end{tabular}



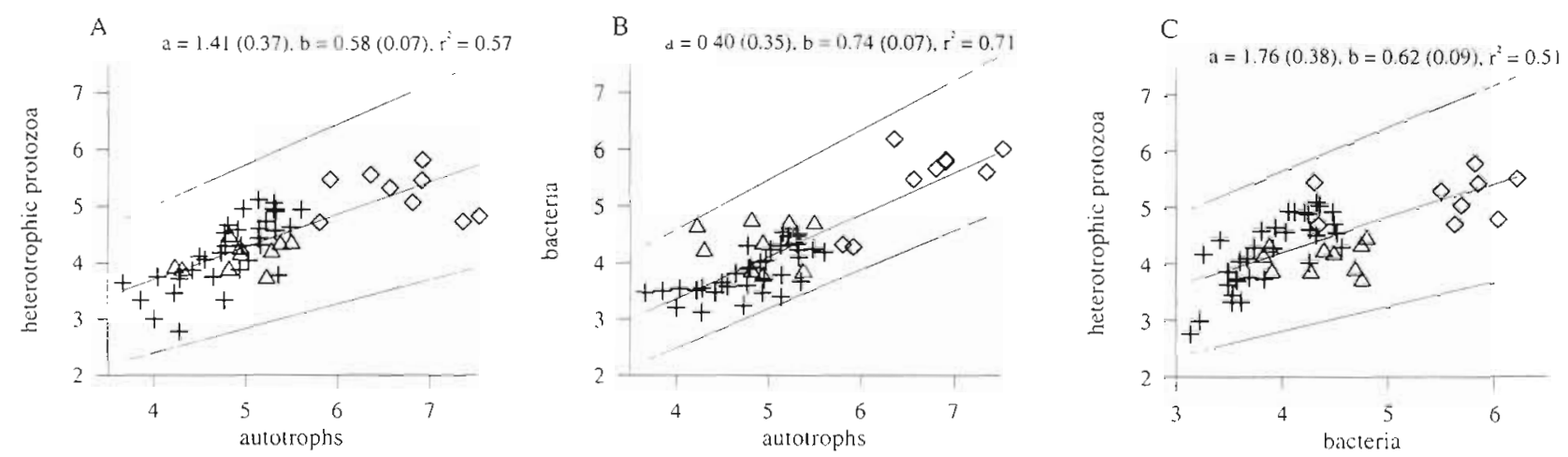

Fig. 6. Relationships between biomass of trophıc categories in sea ice offshore from Davis station. Data are log 10 biomass (pg C $\left.\mathrm{m}^{-1}\right)$ from each sample collected on all 4 sampling dates. Samples representing values from bottom ice $(\diamond)$, interior ice $(+)$ and the pack ice $(\Delta)$ communities are distinguished. Lines represent least squares linear regression together with $95 \%$ confidence untervals. Respective equations are shown

growth rate have been recorded in the bottom community of Arctic sea ice $\left(74^{\circ} 40^{\prime} \mathrm{N}\right)$ (Smith et al. 1989), although growth rates measured by thymidine incorporation in the bottom ice of Frobisher Bay $\left(66^{\circ} 30^{\prime} \mathrm{N}\right)$ were 15 times higher at about $0.75 \mathrm{~d}^{-1}$ (Bunch \& Harland 1990) than the estimates of Smith et al. (1989) from net accumulation of biomass. Pack ice bacteria also grow at similar rates to those measured in Antarctic bottom ice communities (Kottmeier \& Sullivan 1990, Grossmann 1994).

\section{Trophic coupling and carbon flow}

The evidence presented indicates that an active population of heterotrophic protozoa and bacteria exists in the land fast ice offshore from Davis. Questions then arise about the trophic interactions that are taking place and the extent to which autotrophic and heterotrophic biomass is coupled. Microbial interactions in the water column can be highly complex (Fenchel 1988) and as suggested by Palmisano \& Garrison (1993) the same may be true of sea ice communities. Evidence for close coupling between autotrophic, bacterial and heterotrophic protozoan populations within sea ice is illustrated by the relationship between the total biomass of each component in each sample examined during the summer period (Fig. 6). A schematic summary of the changes in microbial carbon biomass and the estimates of carbon flow within and from the sea ice during the austral summer sampling period is given in Fig. 7.

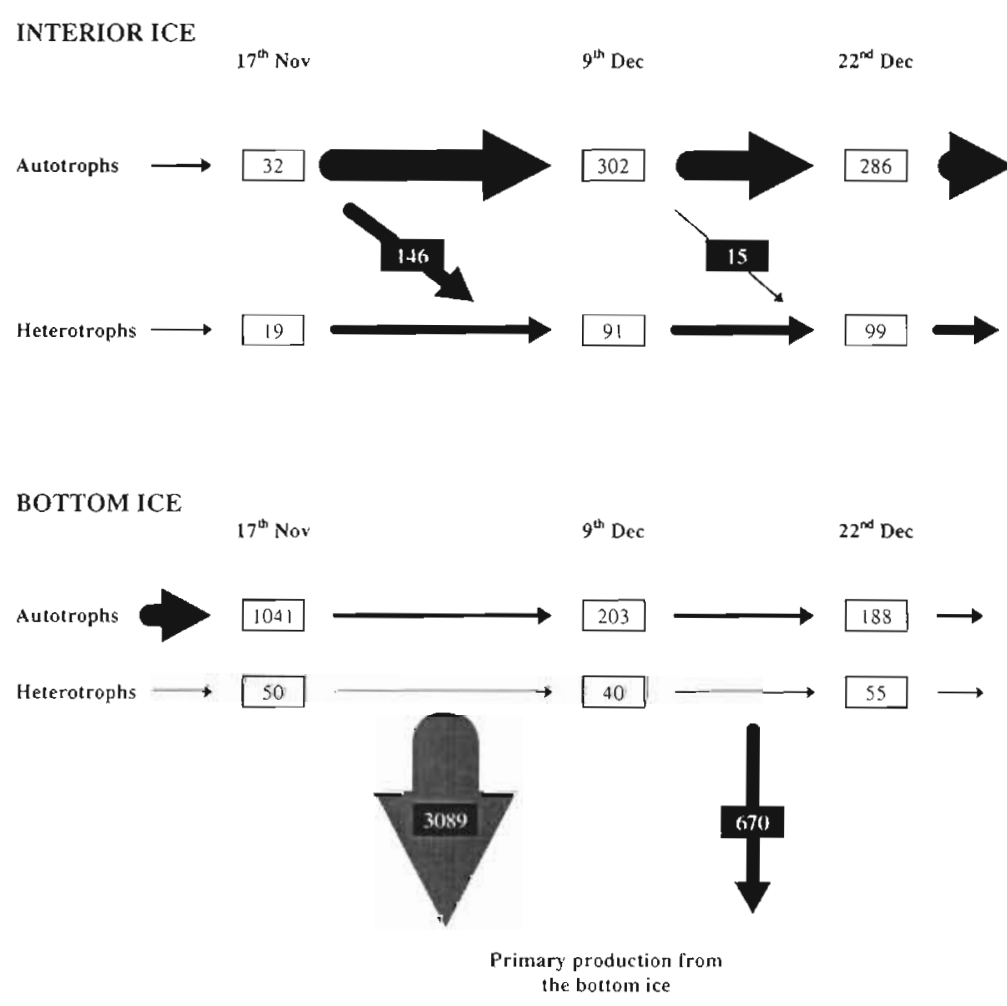

Fig. 7 Schematic summary of changes in microbial carbon biomass and inferred carbon flow within interior and bottom fast ice offshore from Davis station during austral summer 1993/1994. Numbers in white boxes are microscopically determined values of carbon biomass ( $\mathrm{mg} \mathrm{C} \mathrm{m}^{-2}$ ) and those in black boxes are estimations of autotrophic carbon biomass (mg $\mathrm{C}$ $\mathrm{m}^{-2}$ ) consumed by heterotrophs or lost from the ice. Autotrophic production within interior ice was estimated from accumulation of biomass of autotrophic and heterotrophic components between sampling dates. An incorporation efficiency of $40 \%$ was used to estumate consumption of autctrophic production by both heterntrophir nrotozoa and bacteria. Primary production in bottom ice was estimated from measurements of ${ }^{14} \mathrm{C}$ incorporation. Details of calculations of carbon production and flow are discussed in the text 
Acknowledgements. Special thanks are due to Jon Grey tor outstanding help in the field. Thanks also to Carol Robinson, Trevor Bailey and Jason Whitehead for their dedicated field assistance. We also acknowledge the considerable support of the Australian Antarctic Division, in particular Harvey Marchant and Andrew Davidson, and all the friends and colleagues who made up A.N.A.R.E. at Davis during 1993/94. Use of the image analysis system was kindly provided by David Wynn-Williams. Finally, our thanks to Andrew Clarke, Juilan Priddle, Harvey Marchant and 3 anonymous reviewers for their helpful comments on the manuscript. This work was supported by Antarctic Special Topic Grant (GST/02/0656) from the British Antarctic Survey (Natural Environment Research Councill to M.A.S., P.H.B. and R.J.G.L. The work of S.D.A. and R.J.G.L. was carried out in collaboration with the Australian Anterctic Division, Channel Highway, Kingston, Tasmania 7050, Australia.

\section{LITERATURE CITED}

Ackley SF, Sullivan CW (1994) Physical controls on the development and characteristics of Antarctic sea ice biological communities - a review and synthesis. Deep Sea Res 41: $1583-1604$

Arrigo KR, Kremer JN, Sullivan CW (1993a) A simulated Antarctic fast ice ecosystem. J Geophys Res 98 (C4): 6929-6946

Arrigo KR, Robizson DH, Sullivan CW (1993b) A high resolution study of the platelet ice ecosystem in McMurdo Sound, Antarctica: photosynthetic and bio-optical characteristics of a dense microalgal bloom. Mar Ecol Prog Ser 98:173-185

Azam F, Fenchel T, Field JG, Gray JS, Meyer-Reil LA, Thingstad $F$ (1983) The ecological role of water-column microbes in the sea. Mar Ecol Prog Ser 10:257-263

Balech E (1975) Clave ilustrada del Dinoflagelados antarticos. Instituto Argentino, Buenos Aires

Bjørnsen PK, Kuparinen J (1991) Determination of bacterioplankton biomass, net production and growth efficiency in the Southern Ocean. Mar Ecol Prog Ser 71:185-194

Borsheim KY, Bratbak G (1987) Cell volume to cell carbon conversion factors for a bacteriovorous Monas $\mathrm{sp}$. enriched from seawater. Mar Ecol Prog Ser 36:171-175

Buck KR, Bolt PA, Garrison DL (1990) Phagotrophy and fecal pellet production by an athecate dinoflagellate in Antarctic sea ice. Mar Ecol Prog Ser 60:75-84

Bunch JN, Harland RC (1990) Bacterial production in the bottom surface of sea ice in the Canadian Subarctic. Can J Fish Aquat Sci 47:1986-1995

Bunt JS (1960) Introductory studies: hydrology and plankton, Mawson, June 1956-February 1.957 Aust nat antarct Res Exped Rep Ser B (III) Publ 56. Antarct Div, Dept External Affairs, Melbourne

Burkill PH, Edwards ES, John AWG, Sleigh MA (1993) Microzooplankton and their herbivorous activity in the northeastern Atlantic Ocean. Deep Sea Res 40:479-494

Burkill PH, Edwards ES, Sleigh MA (1995) Microzooplankton and their role in controlling phytoplankton growth in the marginal ice zone of the Bellingshausen Sea. Deep Sea Res 42:1277-1290

Caron DA (1991) Evolving role of protozoa in aquatıc nutrient cycles. In: Reid PC, Turley CM, Burkill PH (eds) Protoznd and their role in marine processes. Springer-Verlag, Berlin, p 387-415

Caron DA, Goldman JC (1990) Protozoan nutrient regeneration. In: Capriulo GM (ed) Ecology of marine protozoa.
Oxford University Press, New York, p 283-306

Corliss JO, Snyder RA (1986) Preliminary description of several new ciliates from the Antarctic, including Cohnilembus grassei n. sp. Protistologica 22:39-46

Dieckmann G, Rohardt G, Hellmer H, Kipfstuhl J (1986) The occurrence of ice platelets at $250 \mathrm{~m}$ depth near the Filchner Ice Shelf and its significance for sea ice brology. Deep Sea Res 33:141-148

Fenchel T (1988) Marine plankton food chains. A Rev Ecol Syst 19:19-38

Fenchel T, Lee CC (1972) Studies on ciliates associated with sea ice from Antarctica. I. The nature of the fauna. Arch Protistenkd 114:231-236

Foldvik A, Kvinge T (1977) Thermohaline convection in the vicinity of an ice shelf. In: Dunbar MJ (ed) Polar oceans. Proceedings of the Polar Oceans Conference. McGill University, Montreal, May 1974. Arctic Institute of North America, Calgary, p 247-255

Fry JC, Davies AR (1985) An assessment of methods for measuring volumes of planktonic bacteria, with particular reference to television image analysis. J Appl Bacteriol 58: $105-112$

Garrison DL, Buck KR (1986) Organism losses during ice melting: a serious bias in sea ice community studies. Polar Biol 6:237-239

Garrison DL, Buck KR (1989) The biota of Antarctic pack ice in the Weddell Sea and Antarctic peninsula regions. Polar Biol 10:211-219

Garrison DL, Buck KR (1991) Surface layer assemblages in Antarctic pack ice during the austral spring: environmental conditions, primary production and community structure. Mar Ecol Prog Ser 75:161-172

Garrison DL, Close AR (1993) Winter ecology of the sea ice biota in Weddell Sea pack ice. Mar Ecol Prog Ser 96:17-31

Gifford DJ (1988) Impact of grazing by microzooplankton un. the Northwest Arm of Halıfax Harbour, Nova Scotıa. Mar Ecol Prog Ser 47:249-258

Grossi SM, Koltmeier ST, Moe RL, Taylor GT (1987) Sea ice microbial communities. IV. Growth and primary production in bottom ice under graded snow cover. Mar Ecol Prog Ser 35:153-164

Grossi SM, Kottmeier ST, Sullivan CW (1984) Sea ice microbial communities. III. Seasonal abundance of microalgae and associated bacteria, McMurdo Sound, Antarctica. Microb Ecol 10:231-242

Grossı SM, Sullivan CW (1985) Sea ice microbial communities. $V$ The vertical zonation of diatoms in an Antarctic fast ice community. J Phycol 21:401-409

Grossmann S (1994) Bacterial activity in sea ice and open water of the Weddell Sea, Antarctica: a microautoradiographic study. Microb Ecol 28:1-18

Grossmann S, Dieckmann GS (1994) Bacterial standing stock, activity, and carbon production during formation and growth of sea ice in the Weddell Sea, Antarctica. Appl Environ Microbiol 60:2746-2753

Helmke $E$, Weyland $H$ (1995) Bacteria in sea ice and underlying water of the eastein Weddell Sea in midwinter. Mar Ecol Prog Ser 117:269-287

Hobbie JE, Daley RJ, Jasper S (1977) Use of Nuclepore filters for counting bacteria by fluorescence microscopy. Appl Environ Microbiol 33:1225-1228

Hoshiai T (1977) Seasonal change of ice communities in the sea ice near Syowa Station. Antarctica. In: Dunbar MJ (ed) Polar oceans. Proceedings of the Polar Oceans Conference, McGill University, Montreal, May 1974. Arctic Institute of North America, Calgary, p 307-317

Knox GA (1990) Primary production and consumption in Mc- 
Murdo Sound, Antarctica. In: Kerry KR, Hempel G (eds) Antarctic ecosystems. Ecological change and conservation. Springer-Verlag, Berlin, p 115-128

Kottmeier ST, Grossi SM, Sullivan CW (1987) Sea ice microbial communities. VIII. Bacterial production in annual sea ice of McMurdo Sound, Antarctica. Mar Ecol Prog Ser 35: $175-186$

Kottmeler ST. Sullivan CW (1990) Bacterial biomass and production in pack ice of Antarctic marginal ice edge zones. Deep Sea Res 37:1311-1330

Krebs $W^{\prime} \vee$, Lipps JH, Burckle LH (1987) Ice diatom floras, Arthur Harbour, Antarctica. Polar Biol 7:163-171

Larsen J, Patterson DJ (1991) The diversity of heterotrophic euglenids. In: Patterson DJ, Larsen J (eds) The biology of free-living heterotrophic flagellates. Clarendon Press, Oxford, p 205-218

Legendre L, Ackley SF, Dieckmann GS, Gulliksen B, Horner R, Hoshiaı T, Melnıkov IA, Reeburgh WS, Spindler S, Sullivan CW (1992) Ecology of sea ice biota. 2. Global significance. Polar Biol 12:429-444

Lessard EJ (1991) The trophic role of heterotrophıc dinoflagellates in diverse marine environments Mar Microb Food Webs 5:49-58

Lipps JH, Krebs WN (1974) Planktonic foraminifera associated with Antarctic sea ice. J Foram Res 4:80-85

Lizotte MP. Sullivan CW (1992) Photosynthetic capacity in microalgae associated with Antarctic pack ice. Polar Biol 12:497-502

Mathot S, Becquevort S, Lancelot C (1991) Microbial communities from sea ice and adjacent water column at the time of ice melting in the northwestern part of the Weddell Sea. Polar Res 10:267-276

McConville JM, Mitchell C, Wetherbee R (1985) Patterns of carbon assimilation in a microalgal community from annual sea ice, East Antarctica. Polar Biol 4:135-141

McConville JM, Wetherbee R (1983) The bottom-ice microalgal community from annual ice in the inshore waters of East Antarctica. J Phycol 19:431-439

McManus GB, Fuhrman JA (1988) Control of marine bacterioplankton populations: measurement and significance of grazing. Hydrobiologia 159:59-62

Montagnes DJS, Berges JA, Harrison PJ, Taylor FJR (1994) Estimating carbon, nitrogen, protein, and chlorophyll a from volume in marine phytoplankton. Limnol Oceanogr 39:1044-1060

Palmisano AC, Garrison DL (1993) Microorganisms in Antarctic sea ice. In: Friedmann EI (ed) Antarctic microbiology. Wiley-Liss, Inc, New York, p 167-218

Palmisano AC, Sullivan CW (1983) Sea ice microbial communities (SIMCO) 1. Distribution, abundance, and primary production of ice microalgae in McMurdo Sound, Antarctica in 1980. Polar Biol 2:171-177

Paranjape MA (1990) Grazing by microzooplankton in the eastern Canadian arctic in summer 1983. Mar Ecol Prog Ser 40:239-246

Parsons TR, Maita Y, Lalli CM (1984) A manual of chemical and biological methods for seawater analysis. Pergamon Press, Oxford

Perrin RA, Lu P, Marchant HJ (1987) Seasonal variation in marine phytoplankton and ice algae at a shallow Antarctic coastal site. Hydrobiologia 146:33-46

Porter KG, Feig YS (1980) The use of DAPI for identifying and counting aquatic microflora. Limnol Oceanogr 25:943-948

Putt M, Stoecker DK (1989) An experimentally determined carbon:volume ratio for marine 'oligotrichous' ciliates from estuarine and coastal waters. Limnol Oceanogr 34:1097-1103

This article was submitted to the editor
Scott P, McMinn A, Hosie G (1994) Physical parameters influencing diatom community structure in eastern Antarctic sea ice. Polar Biol 14:507-517

Sherr BF, Sherr EB, Pedros-Alio C (1989) Simultaneous measurement of bacterioplankton production and protozoan bacterivory in estuarine water. Mar Ecol Prog Ser 54 $209-219$

Smith REH, Clement P, Cota GF (1989) Population dynamics of bacteria in Arctic sea ice. Microb Ecol 17:63-76

Sokal RR, Rohlf FJ (1973) Introduction to biostatistics. WH Freeman and Company, San Francisco

Spindler M. Dieckmann GS (1986) Distribution and abundance of the planktic foraminifer Neogloboquadrina pachyderma in sea ice of the Weddell Sea (Antarctica). Polar Biol 5:185-191

Steemann-Nielsen E (1952) The use of radioactive carbon $\left(\mathrm{C}^{14}\right)$ for measuring organic production in the sea. J Cons Perm lnt Explor Mer 18:117-140

Stoecker DK, Buck KR, Putt M (1992) Changes in the sea-ice brine community during spring-summer transition, McMurdo Sound, Antarctica. 1. Photosynthetic protists. Mar Ecol Prog Ser 84:265-278

Stoecker 1)K, Buck KR, Putt M (1993) Changes in the sea-ice brine community during spring-summer transition, McMurdo Sound, Antarctica. II. Phagotrophic protists. Mar Ecol Prog Ser 95:103-113

Sullivan CW, Palmisano AC (1984) Sea ice microbial communities: distribution, abundance, and diversity of ice bacteria in McMurdo Sound, Antarctica, in 1980. Appl Environ Microb 47:788-795

Thomsen HA, Buck KR, Bolt PA, Garrison DL (1991) Fine structure and biology of Cryothecomonas gen. nov. (Protista incertae sedis) from the ice biota. Can J Zool 69: $1048-1070$

Utermöhl H (1958) Zur Vervollkommnung der quantitativen Phytoplankton-Methodik. Mitt Int Verein Theor Angew Limnol 9:1-38

Verity PG, Robertson CY, Tronzo CR, Andrews MG, Nelson JR, Sieracki ME (1992) Relationships between cell volume and the carbon and nitrogen content of marine photosyn thetic nanoplankton. Limnol Oceanogr 37:1434-1446

Watanabe K, Satoh H (1987) Seasonal variations of ice algal standing crop near Syowa Station, East Antarctica, in 1983/84. Bull Plankton Soc Japan 34:131-150

Watanabe K, Satoh H, Hoshiai T (1990) Seasonal variation in ice algal assemblages in the fast ice near Syowa Station in 1983/84. In: Kerry KR, Hempel G (eds) Antarctic ecosystems, ecological change and conservation. SpringerVerlag, Berlin, p 136-142

Watson AJ, Robinson C, Robertson JE, Williams PJLeB, Fasham MJR (1991) Spatial variability in the sink for atmospheric carbon dioxide in the North Atlantic. Nature 350:50-53

Weeks WF, Ackley SF (1982) The growth, structure and properties of sea ice. CRREL Monogr 82-1, US Army CRREL, Hanover, NH

Welch HE, Bergmann MA, Jorgensen JK, Burton W (1988) A subice suction corer for sampling epontic algae. Can J Fish Aquat Sci 45:562-568

Whitaker TM (1977) Sea jce habitats of Signy Island (South Orkneys) and their primary production. In: Llano $G$ (ed) Adaptations within Antarctic ecosystems. Gulf Publishing, Houston, p 75-83

Zwally HJ, Parkinson CL, Comiso JC (1983) Variability of Antarctic sea ice and changes in carbon dioxide. Science 220:1005-1012

Manuscript first received: May 23, 1995

Revised version accepted: December 4, 1995 